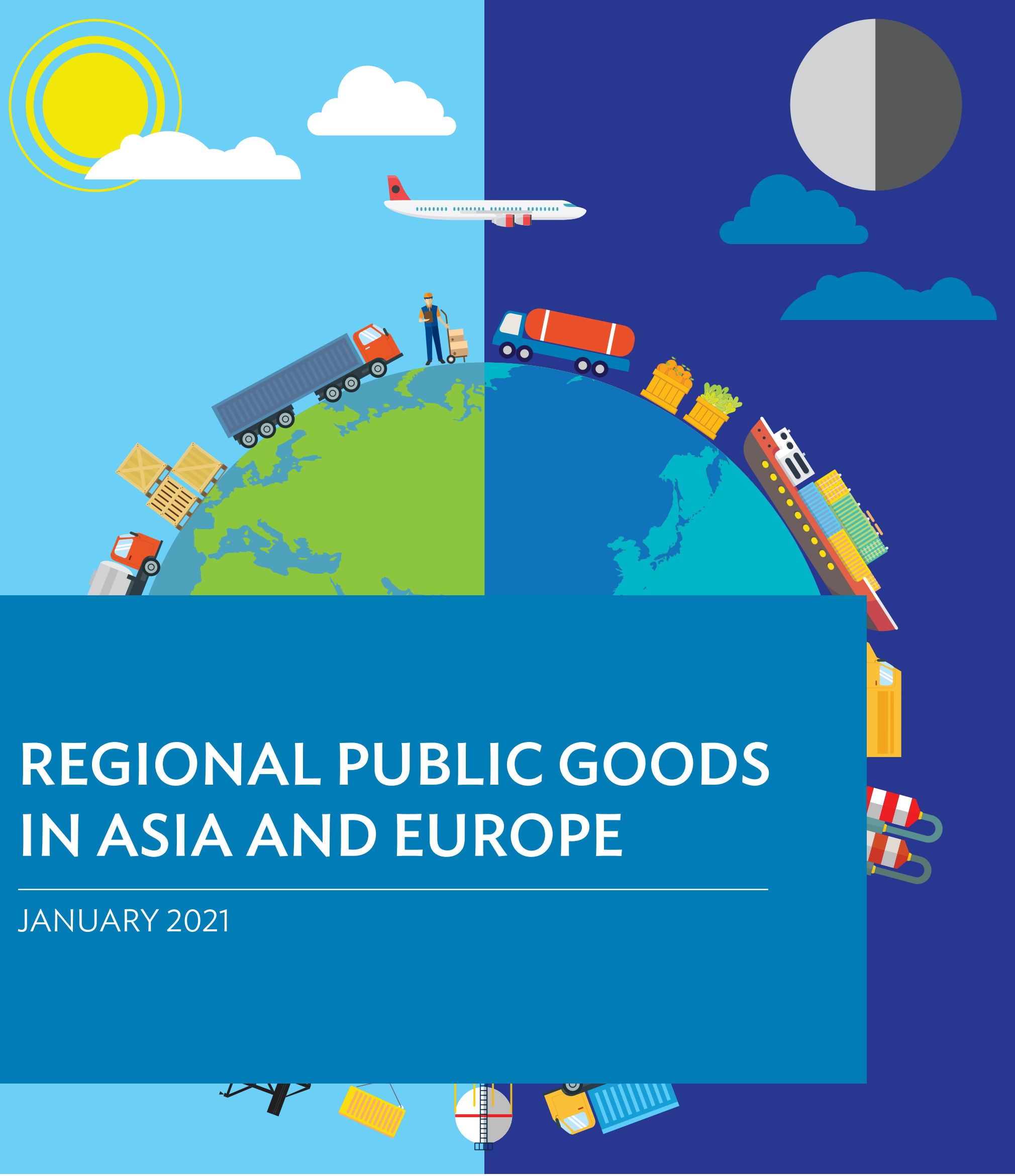





\section{REGIONAL PUBLIC GOODS IN ASIA AND EUROPE}

JANUARY 2021 
(C) 2021 Asian Development Bank 6 ADB Avenue, Mandaluyong City, 1550 Metro Manila, Philippines

Tel +632 8632 4444; Fax +63286362444

www.adb.org

Some rights reserved. Published in 2021.

ISBN 978-92-9262-668-6 (print); 978-92-9262-669-3 (electronic); 978-92-9262-670-9 (ebook)

Publication Stock No. TCS210010-2

DOI: http://dx.doi.org/10.22617/TCS210010-2

The views expressed in this publication are those of the authors and do not necessarily reflect the views and policies of the Asian Development Bank (ADB) or its Board of Governors or the governments they represent.

ADB does not guarantee the accuracy of the data included in this publication and accepts no responsibility for any consequence of their use. The mention of specific companies or products of manufacturers does not imply that they are endorsed or recommended by ADB in preference to others of a similar nature that are not mentioned.

By making any designation of or reference to a particular territory or geographic area, or by using the term "country" in this document, $A D B$ does not intend to make any judgments as to the legal or other status of any territory or area.

This work is available under the Creative Commons Attribution 3.0 IGO license (CC BY 3.0 IGO)

https://creativecommons.org/licenses/by/3.0/igo/. By using the content of this publication, you agree to be bound by the terms of this license. For attribution, translations, adaptations, and permissions, please read the provisions and terms of use at https://www.adb.org/terms-use\#openaccess.

This CC license does not apply to non-ADB copyright materials in this publication. If the material is attributed to another source, please contact the copyright owner or publisher of that source for permission to reproduce it. $\mathrm{ADB}$ cannot be held liable for any claims that arise as a result of your use of the material.

Please contact pubsmarketing@adb.org if you have questions or comments with respect to content, or if you wish to obtain copyright permission for your intended use that does not fall within these terms, or for permission to use the ADB logo.

Corrigenda to ADB publications may be found at http://www.adb.org/publications/corrigenda.

Notes:

In this publication, " $\$$ " refers to the United States dollar and " $€$ " to the euro.

ADB recognizes "Saigon" as Ho Chi Minh City.

Cover design by Michael Cortes. 


\section{Contents}

Tables and Figures

Foreword

Acknowledgments vi vii

Executive Summary vii

$\begin{array}{ll}\text { 1. Introduction } & 1\end{array}$

2. Fundamentals of Regional Public Goods 3

Concepts of Regional Public Goods 3

Market Failures 6

Aggregation Technologies $\quad 6$

$\begin{array}{ll}\text { The Subsidiarity Principle } & 9\end{array}$

3. Case Studies in Asia 11

Early Warnings of Disasters $\quad 11$

Regional Fisheries Management 14

Malaria Control and Elimination 16

Cooperative Management of the Mekong River Basin 18

4. Case Studies in Europe $\quad 22$

Financial Stability in the European Union $\quad 22$

$\begin{array}{ll}\text { Integrated Energy Market } & 25\end{array}$

Mitigating Overpricing in International Mobile Roaming 28

5. Comparative Analysis of Europe and Asia 31

$\begin{array}{ll}\text { Malaria Elimination } & 31\end{array}$

Energy Market Integration $\quad 33$

$\begin{array}{ll}\text { Regional Financial Stability } & 34\end{array}$

$\begin{array}{ll}\text { 6. Conclusions } & 37\end{array}$

$\begin{array}{ll}\text { Background Papers } & 39\end{array}$

\begin{tabular}{l} 
References \\
\hline
\end{tabular} 


\section{Tables and Figures}

\section{Tables}

1 Classification of Goods 3

2 Selected Aggregator Technologies-Characteristics and Recommendations 8

3 Supporting and Detracting Factors for Regional Subsidiarity Factors 10

4 Indian Ocean Tsunami Early Warning System, 2004 and 2014

5 Malaria Risk in Asia and the Pacific, 2010 and 2016

6 International River Basins in Asia 19

7 Road to Currency Unification 23

8 Selected Milestones of Financial Regulation Reform in Europe 24

9 Categorization of Potential Benefits from a Single Energy Market 27

\section{Figures}

1 Classes of Public Goods 4

2 Overview of the Regional Public Good Provision Process 5

3 Placement of Indian Ocean Tsunami Detection Equipment, 2004 and 2014

4 High-Seas Areas Closed to Fishing by the Parties to Nauru Agreement 15

5 The Road Toward the Third European Union Energy Package 26

6 European Union Energy Projects of Common Interest 27

7 Cash Flows in International Mobile Roaming 28

8 Average Wholesale Price per minute for Wholesale Roaming Voice Calls 30 and Data per Megabyte 


\section{Foreword}

Under the ongoing coronavirus disease (COVID-19) pandemic, regional public goods are gaining even greater importance as greater internationalization of economic activities creates crossborder spillovers. When nations engage together in the production and provision of public goods, they generate advances and efficiencies that transcend national interests and help end chronic undersupply of solutions to shared regional problems. For example, in health, a disease outbreak underscores the value of regional public goods such as regional surveillance and control of infectious diseases, and ultimately the importance of elimination in vulnerable countries. Financial contagion transmitted from other countries and regions underlines the value of financial stability and efforts to safeguard it as a regional public good. Agreement among regional groupings to promote more open trade can be also considered a regional public good, while cross-border infrastructure developments such as energy or transport connectivity acknowledge the regional benefits of lowering trade costs among neighboring countries.

This study discusses the theory and policy implementation of regional public goods with useful case studies in Europe and Asia. In a regional setting, eliciting contributions toward collective action in the absence of a transnational authority can be a struggle, or it is often difficult in practice to clearly delineate the boundaries of benefits shared among nations. The case studies highlight how various regional arrangements can be formed to arrive at a functional, if not optimal, provision of regional public goods. Moreover, spillover benefits or costs that cross borders also influence how regional cooperation can be shaped to make the production and provision of regional public goods more effective.

Regional public goods are one of the main pillars of the operational priority of the Asian Development Bank (ADB) on regional cooperation and integration under its Strategy 2030. The bank's role in cultivating the provision of regional public goods reflects its function in facilitating connectivity, trade, investment, finance, knowledge, and partnerships across the region. ADB supports regional initiatives toward regional health security, macroeconomic policy coordination and preventing financial contagion, cross-border soft and hard infrastructure, and climate change mitigation and adaptation.

In focusing on some of the research on how appropriate regional settings can promote collective action for regional public goods to solve pressing issues effectively and efficiently, this publication may help to highlight advances in an important part of the development agenda shared by multiple countries. It can also help policy makers learn about different ways in which the provision of regional public goods can be realized, and how knowledge and measurement of spillover benefits can serve to incentivize greater regional cooperation.

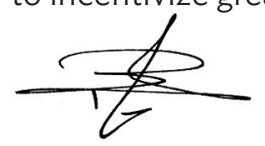

\section{Yasuyuki Sawada}

Chief Economist and Director General

Economic Research and Regional Cooperation Department

Asian Development Bank 


\section{Acknowledgments}

This publication was prepared by the Regional Cooperation and Integration Division (ERCI) of the Economic Research and Regional Cooperation Department (ERCD) of the Asian Development Bank (ADB), with support from Technical Assistance 9210: Enhancing Research Alliance and South-South Development Policy Cooperation Between Asia and the Pacific and Latin America.

The main authors of the report are Junkyu Lee, chief of Finance Sector Group Finance Sector Group of the Sustainable Development and Climate Change Department, Kijin Kim, economist, ERCI/ ERCD, Benjamin Endriga, Mikko Diaz, and Alyssa Villanueva. This report has greatly benefited from the guidance and comments from Cyn-Young Park, director of ERCI.

Background papers were provided by Todd Sandler, Scott Barrett, Guntram Wolff, Gustav Fredriksson, Scott Marcus, Silvia Merle, and Simone Tagliapietra.

Kijin Kim and Paulo Rodelio Halili coordinated the production of this report.

James Unwin edited the report. Michael Cortes created the cover design and implemented the typesetting and layout. Lawrence Casiraya proofread the report, while Jess Macasaet handled the page proof checking. Carol Ongchangco, Marilyn Parra, and Maria Criselda Aherrera provided administrative support. The Printing Services Unit of ADB's Office of Administrative Services and the Publishing Team of the Department of Communications supported printing and publishing. 


\section{Executive Summary}

Globalization and the opening up of economies have led to greater transnational movement of commodities and factors of production. This has fostered many kinds of spillovers across borders. Some, including technology and skills transfer, are welcome, while others are negative impacts such as disease outbreaks, financial contagion, natural disasters, challenges of managing common resources, and others. Such development challenges are of a scale and complexity that are best dealt with through international responses. Their transnational nature has increased demand for regional public goods (RPGs).

By definition, RPGs produce public benefits that extend beyond a country's borders but are limited to a subset of the world. Just like typical (domestic) public goods, they are characterized by varying degrees of nonexcludability and nonrivalry. Nonexcludability refers to it being costly to prevent nonpaying parties from consuming a good's benefits, while nonrivalry implies that consumption can be extended to another user at no increase in spending (zero marginal cost). This gives rise to the "free-rider" problem of who pays for provision. In a national setting, governments can easily tax citizens to provide these goods. In a regional context, the absence of a supranational entity makes this difficult-a basic problem of achieving collective action for RPGs. Therefore, a third property of RPGs is so-called aggregation technology, or how various arrangements can be formed to elicit collective responses. For "best-shot" public goods, for instance, the largest contribution determines the available level. A case in point is vaccines, which are usually best developed by technologically advanced countries who pass on the innovation to other nations. For "weakestlink" public goods, the smallest contribution determines the appropriate level of the good. Disease outbreaks are most likely to occur in countries with the poorest disease-controlling capacity. In this case, policy intervention would be most efficient when directed to vulnerable economies in need of funding and capacity building. A fourth property of RPGs is the scope of their benefits. Whereas the benefits of national and global public goods are more easily determined, this is more challenging for RPGs because the beneficiary and providers may not be always the same. On the other hand, the presence of fewer parties than for global public goods can smooth the path to reaching agreement.

Case studies for Asia and Europe are instructive on how various arrangements are formed to tackle regional development challenges, including the role of regional institutions. In Asia, the Boxing Day Tsunami in 2004 that killed over 230,000 people and affected multiple countries eventually led to a regional approach in adopting an early warning system for disasters. The system adopted a best-shot approach in investing in monitoring equipment, led by the more advanced countries around the Indian Ocean. A key challenge was in maintaining the system for natural hazards such as tsunamis that rarely occur. Besides the RPGs of detection and warning, the national public good of rescue and evacuation is also needed to help communities at risk. 
A second case study on preventing overfishing of tuna in the Pacific Ocean highlights the need to monitor the locations of fishing vessels and limiting their time at sea. This proved a second-best approach as monitoring their harvests was too costly. The third case features the serious health risk posed by malaria in Asia, and highlights that control or reducing its incidence is a national public good, while its elimination to zero cases can be both a national and a regional public good. It can also mitigate the spread of the disease globally, especially to sub-Saharan Africa. Regional institutions like Asian Development Bank (ADB) have provided resources toward a trust fund to combat the disease. The latest example of health-related RPG is ADB's Greater Mekong Subregion (GMS) Health Security Project for the GMS countries to address health threats from the coronavirus disease (COVID-19) pandemic. Similarly, the case on cooperative management of the Mekong River Basin suggests that the ADB-led GMS Economic Cooperation Program can provide a forum for addressing conflicting uses by different countries.

The first European case study discusses how the goal of exchange rate stability led to the push toward monetary integration by the European Union (EU). Periodic financial crises led to the creation of supranational institutions to safeguard financial integration and enhance macroeconomic and financial stability. The second case study discusses energy market integration to improve access and secure supplies. This has resulted in common legislation to liberalize markets and harmonize regulations, and funding mechanisms that support infrastructure in the region. The third case study on mitigating overpricing in international mobile roaming shows that a regional approach was needed since no national regulator could address issues in both home and visited networks.

A comparative analysis of RPG provision in the two regions suggests some lessons for Asia. In the successful drive toward malaria elimination in Eastern Europe and Central Asia, World Health Organization (WHO) Europe adopted a regional approach to employing dedicated staff and technical expertise. This contributed to developing national malaria strategies, initiating crossborder and regional coordination, and obtaining funding from donors such as the Global Fund to Fight AIDS, Tuberculosis and Malaria.

This also improved expertise in disease management, epidemic preparedness and response, integrated vector control, malaria surveillance, and other areas. Asia, including the GMS, follows this provision of weakest-link RPGs and is learning from WHO's success in Europe. In energy integration, an important lesson from European experience is that developing software for an integrated energy market needs both political will and technical cooperation. This requires progress in the adoption of legislative packages and harmonized laws.

The European experience also suggests that integration should be pursued first at the subregional level, where delivery of services supports the development of an integrated energy market. On regional financial stability, experience from Europe shows that coordination is easier to achieve than voluntary cooperation. While Europe relied on supranational institutions, this approach may not be suitable for Asia. The formation of financial stability networks highlights the importance of regional institutions in coordinating provision of RPGs. Experiences in the Association of Southeast Asian Nations and the EU influenced both the creation of the Chiang Mai Initiative and its ensuing financial mechanism in Asia, and the European Financial Stability Fund, the European Financial Security Mechanism, and the European Stability Mechanism.

The provision of RPGs is closely related to regional cooperation and integration. European experiences in malaria elimination, energy market integration, and regional financial stability have highlighted the important role of regional institutions in promoting regional cooperation 
and integration, and in the provision of RPGs. The case studies for Asia show that provision can be initiated and supported by agreements and declarations, rather than the formal institutions established in Europe. The case studies also illustrate the superior benefits from forging a regional approach rather than countries initiating policies on their own. This underscores the role of regional institutions in drawing countries toward the advantage of regional cooperation.

Multilateral development banks can provide needed "strong pressure" and can help increase provision through narrowing knowledge and financing gaps, providing a permanent platform for continuous dialogue, and by being honest brokers to enhance mutual trust concerning RPGs. Moreover, coordination among global, regional, and subregional institutions can also enhance provision through complementarity and alignment of goals and strategies. 



\section{Introduction}

Globalization through more open trade and investment policies over the past half century has led to greater prosperity and efficient allocation of resources by allowing goods, financial capital, and labor to move across borders in search of the highest returns. Although this has created cross-border spillovers of skills and technology transfer, disease outbreaks, financial contagion, disaster events, and other effects have also gained mobility. As economies become more integrated, development challenges are becoming more transnational-and this requires global or regional responses. The provision of regional public goods (RPGs), whose benefits extend beyond a single nation's territory to a well-defined region, is such a response (Sandler 2013). RPGs include joint disease surveillance and elimination through immunization, protocols for managing shared resources such as marine fisheries, closer coordination of macroeconomic policies, cross-border infrastructure and connectivity, and so on.

RPGs can play an important role in sustainable economic development at the national and regional levels by addressing common development issues across borders. While public goods in general have very limited market provision arising from their publicness, governments and regional institutions can act to enhance their supply. Regional institutions have made efforts to enhance knowledge and financial support for projects that are regional in their scope of benefits. Facilitating the provision of RPGs is also one of the operational priorities of regional development banks such as the Asian Development Bank (ADB) to promote sustainable economic development for developing member countries.

A key challenge in providing RPGs stems from lack of incentives for countries to provide resources. Countries may fail to supply enough RPGs on their own because they do not consider the potential benefits that might be spread by joining forces with neighbors. As such, provision often requires collective action. However, the institutional arrangements to promote this may not be clear because RPGs generate benefits that do not fall under established political jurisdictions (Sandler and Arce 2002). Compared to domestic or global public goods, measuring the benefits of regional public goods is more difficult.

Despite these challenges, the provision of RPGs will likely remain salient as many regions including Asia and the European Union (EU) seek closer integration and cross-border cooperation. In Asia, for instance, the tsunami that killed over 230,000 people in 2004 led to a regional integrated early warning system being put in place to save costs and maximize the benefits of early warnings. Regional cooperation toward sustainable fisheries management in the Pacific islands helps prevent overfishing, while cooperative management of the Mekong River Basin is needed to enable multiple uses such as hydropower, irrigation, and fisheries. Malaria also poses a health risk and requires Asian and global coordination for its control and elimination. In the EU, the exchange rate stability goal has prompted closer cooperation in macroeconomic policies and prudential management 
of the financial system. The objective to achieve an integrated energy market with lower prices and more stable supply requires cross-border hardware infrastructure and harmonized energy market policies. Lowering prices of international mobile network roaming in the EU also requires regional standards.

This report reviews the concept of RPGs and the challenges and benefits in their provision in Asia and Europe. It provides case studies and a comparative analysis of the regional arrangements taken toward RPG provision in both regions. Section 2 discusses the concept of RPGs and their properties. Section 3 examines case studies for Asia, which include early warnings of disasters, regional fisheries management, and malaria control and elimination in the region. Case studies in Europe are discussed in section 4, which include the EU experience in monetary integration and financial stability, energy integration, and mitigating overpricing in international mobile roaming. Section 5 provides a comparative analysis of RPGs in the two regions focusing on lessons for Asia, while section 6 concludes. 


\section{Fundamentals of Regional Public Goods}

\section{Concepts of Regional Public Goods}

The concept of "public goods" reached maturity in the middle of the 20th century. Paul Samuelson, in his seminal 1954 paper "The Pure Theory of Public Expenditure," laid the foundation for the contemporary theory of these goods by offering their first mathematical definition. Public goods are commonly defined in two "classic" properties. First, public goods are nonexcludable, implying that once provided, their benefits can be consumed by payers and nonpayers. Second, they are nonrival, meaning that consumption by one party does not diminish the consumption opportunities of others (Cornes and Sandler 1996).

Two other kinds of good are a mixture of these extremes (Table 1):

Club goods involve some exclusivity but no rivalry among the group of users. An example is a toll road that is not congested (congestion implies rivalry).

Common property resources involve rivalry but not exclusivity. An example is a fishery that restricts access to just members of a community. All members of the community have access, but each member's harvest reduces the stock of fish available to others.

\section{Table 1: Classification of Goods}

\begin{tabular}{|c|c|c|}
\hline Principle & Rivalry & Nonrivalry \\
\hline Exclusivity & Private good & $\begin{array}{l}\text { Club good } \\
\text { (impure public goods) }\end{array}$ \\
\hline Nonexclusivity & $\begin{array}{l}\text { Common-pool resource } \\
\text { (impure public goods) }\end{array}$ & Pure public good \\
\hline
\end{tabular}

Source: Asian Development Bank (2018).

One important point about these goods is the role that government plays in determining their properties. A book is a private good, but the words contained in the book are only private if protected by copyright laws. Knowledge is a public good, but inventions are private when under patent. Given that a book has been written and an invention invented, efficiency requires that access be based on marginal cost, which ignores the sunk cost incurred in creating these goods. However, if the writer and inventor could not hope to recover their costs, they may not have written the book or invented the item in the first place. Copyright and patent laws exist to provide these incentives. 
Public goods are jurisdictional in nature. They may be local, national, international, regional, or global. The quintessential national public good is national defense. International public goods are shared by many countries, irrespective of their geography. Regional public goods (RPGs) are shared by a multitude of neighboring countries. An example is flood protection within a river basin. Global public goods are available to be consumed by people everywhere. An example is protection of the ozone layer.

Between national public goods and global public goods lies the distinct class of RPGs. These produce public benefits that extend beyond a border but are limited to a subset of the world. Various types of public goods are distinguished by the scope of their benefits (Figure 1). At one end of the spectrum, national public goods produce public benefits that remain within a country's borders. An example includes national parks, since their benefits are restricted to one country. At the other end, global public goods-such as combatting climate change-produce benefits worldwide. Reducing air pollution can be considered an example of an RPG as it provides benefits to a country and its neighbors. RPGs can have spillover benefits nationally and globally. The difficulty in determining the scope of its benefits aside from being nonrival and nonexcludable can be a challenge in providing such goods.

Regional institutions also vary in their operational definition of RPGs. ADB regards RPGs as necessary to foster regional cooperation and integration, and includes various sectors such as addressing financial and disaster risks, improving cross-border health security, assisting developing member countries in managing shared resources as well as implementing 21st Conference of the Parties (COP21) commitments and similar agreements with regional impact. The African Development Bank has a more focused definition, where RPGs are confined mostly to regional infrastructure development.

\section{Figure 1: Classes of Public Goods}

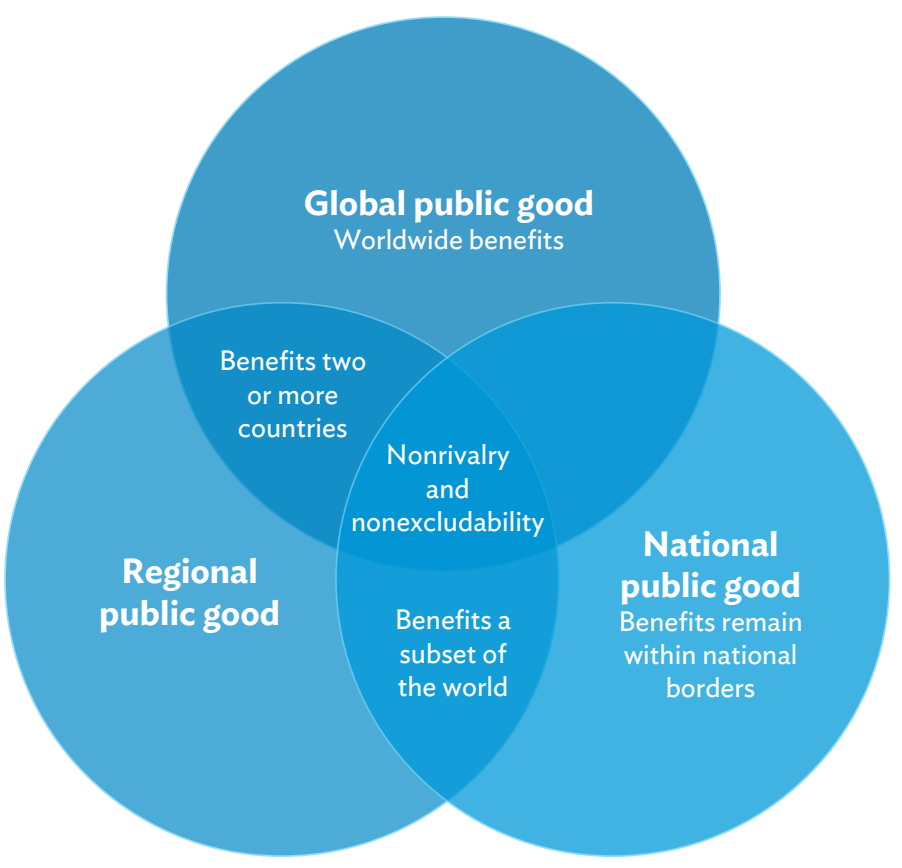

Source: Asian Development Bank (2018). 
RPG provision is a complex process that requires identifying the shortage, type of goods, characteristics of the supply without intervention, and potential policy responses. Four key properties of RPGs determine countries' incentives to contribute and the scope for collective action (Figure 2): the degrees of (i) nonexcludability, (ii) nonrivalry, (iii) aggregation technology (how individual contributions add up to make the public good socially available), and (iv) the scope of benefits. The effectiveness of provision mechanisms mainly depends on these properties and potential interventions should therefore be tailored.

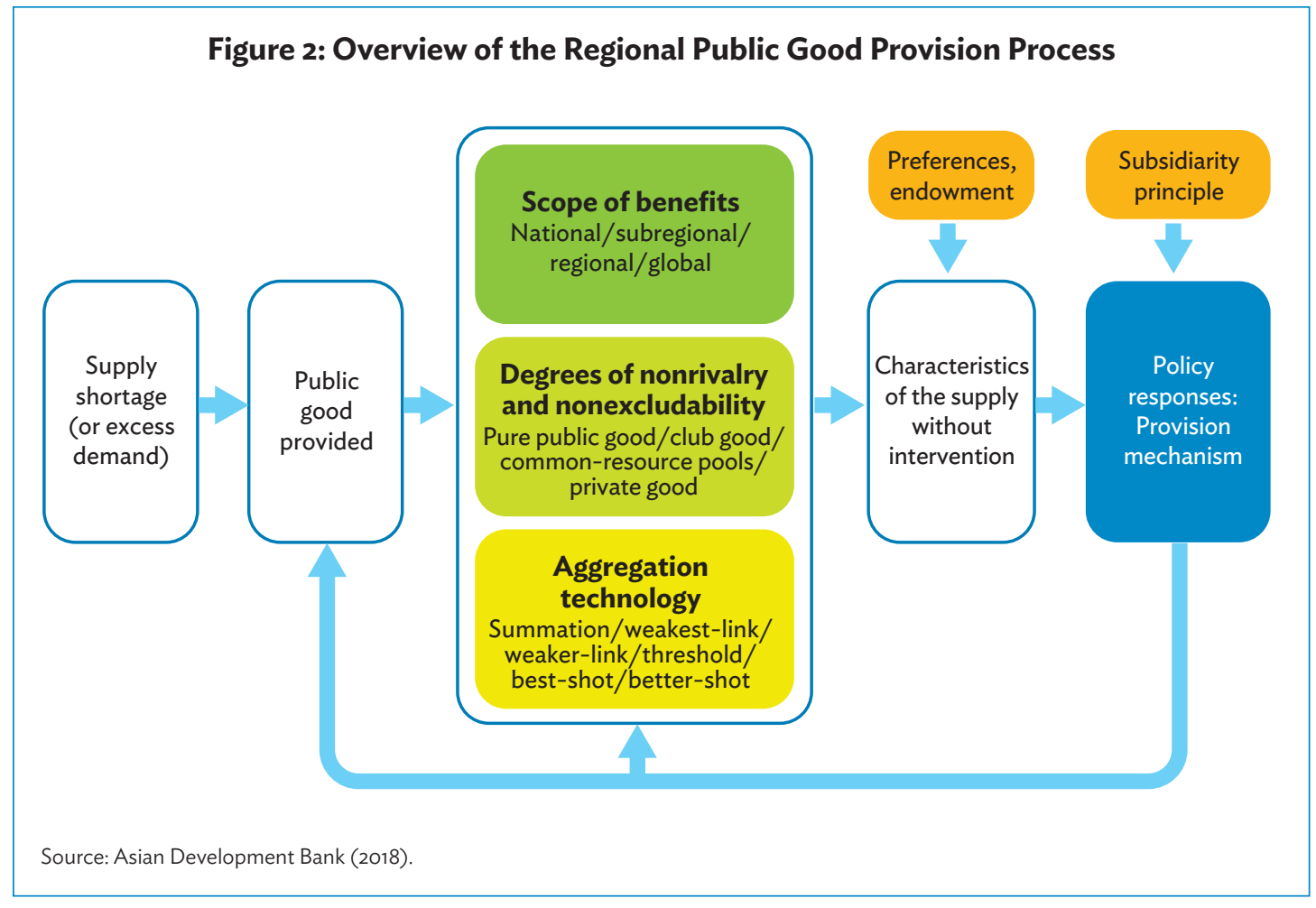

The provision of RPGs may be more challenging than for global public goods. First, some regions lack a dominant country and consequently leadership in providing RPGs. This issue may be less severe on a global level, as developed countries may either lead by example by providing the global public goods themselves or encourage other countries to contribute to provision (Sandler and Arce 2002). Second, regions may be prone to rivalries and local disagreements that reduce the scope for collaboration (Collier et al. 2003; Sandler 2013). Third, donors have traditionally relied on global and national institutions, as opposed to regional institutions, to provide public goods (Sandler 2013). Regional institutions that are often in the best position to promote the provision of RPGs may therefore have weaker reputation, experience, and capacity (Sandler 2006).

On the other hand, factors such as a smaller number of participants and proximities in geography and culture can mean they are easier to supply than global public goods. Cooperation is more likely to succeed if the group is small and coercion between members is strong (Olson 1965). Countries in a region are located close to each other and may be culturally similar (Estevadeordal and Goodman 2017). As such, they are more likely to interact regularly and have strong incentives to abide by agreements (Sandler 2006). These can give more scope for collective action than for global public goods by reducing the costs of cooperation or enforcing agreements to provide RPGs. 


\section{Market Failures}

The nonexcludability and nonrivalry properties of public goods give rise to market failures that may be reined in by policy intervention. Nonexcludability implies that it is costly to prevent nonpaying parties from consuming a good's benefits. The incentive to contribute to providing nonexcludable RPGs may be weak because of free-riding, where other countries are relied on to solve problems. Market failures are also caused by nonrivalry of benefits, which implies there is no marginal cost when consumption is extended to another user (Hardin 1997). An efficient allocation of nonrival RPGs requires that the price of the public good also has zero marginal cost. However, charging a price above zero for nonrival RPGs is allocatively inefficient, since new users would be charged to use the good even if it costs nothing to include them. The inefficiency can be reduced if governments tax its consumption and redistribute revenue. However, citizens' valuation of the good is often difficult to estimate. Taxing at a transnational level may require a supranational authority, which may not exist (Sandler and Arce 2002).

The inefficiency associated with impure public goods is less extreme than for pure public goods if some exclusion is practiced to account for consumption-related incremental costs such as user charges. Club goods such as a highway network are subject to congestion; in this case toll charges can enhance efficiency by internalizing crowding externalities. If no crowding- or rivalry-internalizing tolls are charged, then impure public goods are overused. For pure public goods, even if exclusion could be practiced, nonrivalry means that is inadvisable, because there is no incremental cost when extending consumption to others (Sandler 2004). Social welfare declines when exclusion is practiced with a pure public good.

\section{Aggregation Technologies}

In addition to nonexcludability and nonrivalry, a third property of publicness is aggregator technology. This indicates how provision, whether through individual or collective contributions, determines the overall quantity available for consumption (Table 2).

Traditionally, the summation aggregator was assumed for all forms of public goods, where the overall public good equals the sum of the contributors' provision (Samuelson 1954, 1955). This aggregator makes each contributor's supply or provision effort a perfect substitute for that of other contributors, encouraging free-riding and underprovision.

For example, in reducing greenhouse gas emissions, the overall reduction would be equal to the sum of the decrease in each country's emissions. However, a non-contributing country can easily enjoy the benefits of mitigating climate change by free-riding. This problem can result in the aggregate reduction much less than needed. As such, regional and subregional institutions can fund RPGs with the summation technology through loans or grants. Efforts to fund RPGs can be bolstered by charitable foundations, partnerships, or nongovernment organizations.

For a weighted-sum aggregator, each contributor's provision is assigned an empirically determined weight when determining the overall level of the public good. Weighted-sum aggregators have less free-riding incentives as countries are informed about how they impact provision. Examples include the reduction of acid rain or river pollution, for which a country's location affects its ability to clean up the pollutant. In an acid rain scenario, downwind countries are the main recipients of depositions and are, therefore, motivated to reach agreement with other countries to control sulfur and nitrogen 
emissions. When regional and subregional institutions take a lead to bolster countries' actions, scientific monitoring data ${ }^{1}$ allow these institutions to distribute their resources among countries, where these resources can have the greatest effect based on spatial and other factors.

For a weakest-link aggregator, the smallest contribution determines the aggregate. Weakest-link aggregation for instance is associated with actions that curb the spread of an infectious disease. Disease outbreaks are most likely to occur in countries with the poorest disease-controlling capacity. Policy intervention would be efficient when directed to vulnerable economies in need of funding and capacity building. If all countries in a region have the same endowments and preferences, weakestlink public goods present less efficiency concerns. That is, wasting resources is unlikely because each country's provision may match the smallest contribution. When endowments differ and poorer countries cannot afford to contribute, regional and subregional institutions can assist by providing grants and capacity building.

A less extreme form of weakest link is weaker-link, where the smallest contribution has the greatest influence on the aggregate level, followed by the second-smallest contribution, and so on (Cornes 1993; Cornes and Sandler 1996; Sandler 1992). When endowments differ by country, shoring-up efforts are still needed by regional and subregional institutions.

The threshold aggregator is where provision of the public good meets or exceeds a certain level before benefits are generated. Threshold RPGs offer greater incentive than summation RPGs to act until the threshold is obtained. A higher threshold provides more incentives to provide toward an efficient outcome. For example, in eliminating infectious diseases such as malaria in a region, countries may take possible measures independently and/or collectively to ensure that the required aggregate effort is reached. Regional and subregional institutions can identify or design a threshold to achieve more efficient provision. These institutions can also pool efforts by contributing funds of their own and reaching out to other institutions.

For best-shot public goods, the largest contribution determines the available level. For example, development of vaccines would have the best chance of success if the most technologically advanced country takes a lead. Loans are appropriate to assist best-shooter countries. At the regional level, the issue becomes a coordination issue when there are many potential best-shooter countries because only a single capable country needs to provide the best-shot RPGs. Regional institutions can coordinate and prioritize actions among leader countries. If the best-shooter country is not available, then regional institutions can pool actions or coordinate among subregions. For large-scale best-shot RPGs, funds from global institutions or other multilateral institutions can be requested.

Better-shot public goods are a softer version of best shot, for which the largest contribution has the biggest marginal influence on the overall provision, followed by the second-largest contribution, and so on. Better-shot public goods require less hegemony, pooling of actions, and outside intervention. Since more than one country are willing to provide, there is also less need to coordinate or concentrate provision activity.

The Convention on Long-Range Transboundary Air Pollution program and the Acid Deposition Monitoring Network are intended to ascertain these weights based on the monitored dispersion of pollutants from the source to the recipient countries (Chung 2017). 


\section{Table 2: Selected Aggregator Technologies-Characteristics and Recommendations}

\begin{tabular}{|c|c|c|c|}
\hline Functional Areas & Aggregator & Regional Institutions & Policy Considerations \\
\hline $\begin{array}{l}\text { Natural Resources } \\
\text { and Environment } \\
\text { Addressing water } \\
\text { pollution, curbing } \\
\text { acid rain, commons } \\
\text { management, } \\
\text { reducing } \\
\text { greenhouse gases }\end{array}$ & $\begin{array}{l}\text { Summation, } \\
\text { weighted sum }\end{array}$ & $\begin{array}{l}\text { Acid Deposition } \\
\text { Monitoring Network in } \\
\text { East Asia; Long-Range } \\
\text { Transboundary Air } \\
\text { Pollution in Northeast } \\
\text { Asia; Pacific Island } \\
\text { Renewable Energy } \\
\text { Investment Program }\end{array}$ & $\begin{array}{l}\text { - Setting up pollution monitors } \\
\text { and identification of emitter and } \\
\text { recipients requires funding at the } \\
\text { regional and subregional levels } \\
\text { Grants can be used to fund poor } \\
\text { countries' contribution to the } \\
\text { disaster monitoring system } \\
\text { For assistance after a disaster } \\
\text { (a summation technology), rich } \\
\text { countries, charitable foundations, } \\
\text { and nongovernment organizations } \\
\text { have roles to play } \\
\text { Multilateral institutions and } \\
\text { networks should bolster regional } \\
\text { actions to address GPGs }\end{array}$ \\
\hline $\begin{array}{l}\text { Economic } \\
\text { Cooperation and } \\
\text { Integration } \\
\text { Free trade } \\
\text { agreements, } \\
\text { fostering foreign } \\
\text { direct investment, } \\
\text { maintaining } \\
\text { financial stability, } \\
\text { promoting } \\
\text { macroeconomic } \\
\text { stability, fostering } \\
\text { regional growth }\end{array}$ & $\begin{array}{l}\text { Summation, } \\
\text { weakest-link, } \\
\text { best-shot }\end{array}$ & $\begin{array}{l}\text { Greater Mekong } \\
\text { Subregion (GMS) } \\
\text { Program; South Asian } \\
\text { Association of Regional } \\
\text { Cooperation; Association } \\
\text { of Southeast Asian } \\
\text { Nations (ASEAN); } \\
\text { Central Asia Regional } \\
\text { Economic Cooperation; } \\
\text { Free Trade Area of the } \\
\text { Asia-Pacific; South } \\
\text { Asia Free Trade Area; } \\
\text { Chiang Mai Initiative } \\
\text { Multilateralization }\end{array}$ & $\begin{array}{l}\text { - In terms of maintaining regional } \\
\text { financial stability, sound financial } \\
\text { practices (best-shot RPGs) } \\
\text { including well-established bond } \\
\text { markets, emergency liquidity pools, } \\
\text { or agreements with multilateral } \\
\text { institutions can enhance resiliency } \\
\text { to the regional financial system } \\
\text { In the case of poor countries, grants } \\
\text { would be appropriate for constant } \\
\text { surveillance to spot liquidity and } \\
\text { other difficulties that could infect } \\
\text { neighboring countries' banking } \\
\text { systems (weakest-link RPGs) }\end{array}$ \\
\hline $\begin{array}{l}\text { Human and Social } \\
\text { Development } \\
\text { Education, health, } \\
\text { knowledge creation, } \\
\text { culture, furthering } \\
\text { science }\end{array}$ & $\begin{array}{l}\text { Weakest-link, } \\
\text { weaker-link, } \\
\text { best-shot, } \\
\text { better-shot }\end{array}$ & $\begin{array}{l}\text { GMS Health Security } \\
\text { Project; International } \\
\text { Rice Research Institute; } \\
\text { ASEAN Quality } \\
\text { Assurance Framework }\end{array}$ & $\begin{array}{l}\text { Regional and subregional institutions } \\
\text { have a greater role to play for } \\
\text { weakest-link health RPGs, such as } \\
\text { quarantine and surveillance efforts } \\
\text { to contain potential global impact of } \\
\text { contagious diseases } \\
\text { Grants are needed to bolster } \\
\text { the actions of poor weakest-link } \\
\text { countries } \\
\text { Regional and global health efforts } \\
\text { should be complementary and } \\
\text { reinforcing }\end{array}$ \\
\hline $\begin{array}{l}\text { Governance and } \\
\text { Institutions } \\
\text { Regulatory } \\
\text { practices, regional } \\
\text { collectives, rule } \\
\text { of law, banking } \\
\text { practices, } \\
\text { benchmarking } \\
\text { data, capacity } \\
\text { building, policy } \\
\text { harmonization, } \\
\text { surveillance }\end{array}$ & $\begin{array}{l}\text { Best-shot, } \\
\text { better-shot, } \\
\text { threshold, } \\
\text { weakest-link }\end{array}$ & $\begin{array}{l}\text { Economic Review } \\
\text { and Policy Dialogue; } \\
\text { South Asian } \\
\text { Telecommmunication } \\
\text { Regulators } \\
\text { Council; ASEAN+3 } \\
\text { Macroeconomic } \\
\text { Research Office }\end{array}$ & $\begin{array}{l}\text { To promote the best practices, } \\
\text { regional institutions' capacity- } \\
\text { building efforts would be } \\
\text { recommended particularly for those } \\
\text { weakest-link countries } \\
\text { To apply the very best practices, } \\
\text { the region should look to the entire } \\
\text { world, especially the most successful } \\
\text { industrial countries, and borrow } \\
\text { practices that have worked }\end{array}$ \\
\hline
\end{tabular}




\begin{tabular}{|c|c|c|c|}
\hline $\begin{array}{l}\text { Peace and Security } \\
\text { Peacekeeping, } \\
\text { crisis management, } \\
\text { limiting weapon } \\
\text { proliferation, } \\
\text { managing refugee } \\
\text { flows, territorial } \\
\text { dispute resolution, } \\
\text { alliance, curbing } \\
\text { drug trafficking, } \\
\text { controlling } \\
\text { terrorism, limiting } \\
\text { corruption }\end{array}$ & $\begin{array}{l}\text { Best-shot, } \\
\text { better-shot } \\
\text { threshold, } \\
\text { weakest-link }\end{array}$ & $\begin{array}{l}\text { No region-wide Asia and } \\
\text { Pacific alliance. Some } \\
\text { non-aggression pacts } \\
\text { (e.g., India and Pakistan } \\
\text { and the People's Republic } \\
\text { of China and Pakistan); } \\
\text { Alliances with the United } \\
\text { States and ASEAN. }\end{array}$ & $\begin{array}{l}\text { - An alliance structure that links the } \\
\text { region would allow for more rapid } \\
\text { responses to conflict exigencies } \\
\text { Actions to shore up unstable } \\
\text { regimes must be undertaken, ideally } \\
\text { at the subregional level that richer } \\
\text { subregions (e.g., East Asia) are able } \\
\text { to address }\end{array}$ \\
\hline $\begin{array}{l}\text { Connectivity } \\
\text { Transportation } \\
\text { network, } \\
\text { infrastructure, } \\
\text { customs control, } \\
\text { communication } \\
\text { network, energy } \\
\text { network, air traffic } \\
\text { control }\end{array}$ & $\begin{array}{l}\text { Weakest-link, } \\
\text { weaker-link, } \\
\text { threshold }\end{array}$ & $\begin{array}{l}\text { Border economic zone } \\
\text { development; East Asia } \\
\text { and Pacific Infrastructure } \\
\text { Regulatory Forum; } \\
\text { South Asia Forum for } \\
\text { Infrastructure Regulation; } \\
\text { Turkmenistan- } \\
\text { Uzbekistan-Tajikistan- } \\
\text { Afghanistan-Pakistan } \\
\text { Power Interconnection } \\
\text { Framework; GMS } \\
\text { Cross-Border Transport } \\
\text { Facilitation Agreement }\end{array}$ & $\begin{array}{l}\text { - Connectivity action should first be } \\
\text { at the subregional level, followed by } \\
\text { regional efforts to link the subregions } \\
\text { When congestion tolls are used to } \\
\text { internalize the associated crowding } \\
\text { costs, the toll proceeds can be used } \\
\text { to finance the club and achieve an } \\
\text { efficient solution } \\
\text { Equity concerns can be addressed by } \\
\text { regional or subregional institutions } \\
\text { through funding the user charges or } \\
\text { tolls of poor countries }\end{array}$ \\
\hline
\end{tabular}

ASEAN+3 $=$ Association of Southeast Asian Nations Plus Three (includes the 10 ASEAN members plus the PRC, Japan, and the Republic of Korea), GPG = global public good, RPG = regional public good.

Sources: ADB (2018) and Sandler (2018a, 2018b).

\section{The Subsidiarity Principle}

The subsidiarity principle indicates that allocative efficiency is achieved when an institution's jurisdiction matches the benefit range of the public good precisely (Olson 1969; Sandler 2004, 2006). ${ }^{2}$ If the public good's range of spillover benefits is greater than the institution's jurisdiction whose members supply the public good, provision decisions will fail to account for some benefit recipients, resulting in undersupply. On the other hand, if the range of spillover benefits is smaller than the institution's jurisdiction, over-provision is anticipated as nonrecipients cover some of the good's provision cost. This implies that global public goods should be provided or assisted by global institutions, while RPGs should be provided or assisted by regional institutions. The International Monetary Fund for instance supports financial stability globally, while the United Nations Conference of the Parties encourages global collective action on climate change. Regional institutions like ADB support regional initiatives on free trade agreements, liquidity support through the Chiang Mai Initiative Multilateralization, river basin management in the Greater Mekong River Subregion, and marine fisheries management in the Pacific.

Adherence to subsidiary can boost efficiency, reduce transaction costs, and promote institutional evolution and innovation (Table 3). On the other hand, economies of scale may justify an RPG-

2 The subsidiarity principle is often discussed in political science when it comes to the functional roles of local and central authorities, suggesting that problems should be addressed at the lowest or immediate administrative level. 
providing jurisdiction whose domain exceeds that of a good's spillover range if the reduced unit costs offset any inefficiency losses. For example, in peacekeeping missions, the United Nations can achieve scale economies which may not be achievable at regional or subregional level. Similarly, economies of scope refer to cost-savings when two or more RPGs are supplied by the same institution regardless of heterogeneous benefit recipients. Tailoring jurisdictions to these spillover ranges would result in a proliferation of jurisdictions, which is costly to support. In practice, when the requisite regional institution or jurisdiction is absent, the next nearest (smaller or larger) jurisdiction can play that role.

\section{Table 3: Supporting and Detracting Factors for Regional Subsidiarity Factors}

\section{Supporting Factors}

- Bolsters efficiency by matching recipients' marginal gains with marginal provision costs

- Curtails tax spillovers to nonbeneficiaries, fostering efficiency

- Limits transaction costs by augmenting repeated interactions, reducing asymmetric information, and curtailing the number of participants

- Promotes the evolution of regional institutions based on shared culture, experiences, challenges, norms, and values

- Fosters intraregional institutional innovations

- Focuses on participants with the most at stake

\section{Detracting Factors}

- Economies of scale favor larger jurisdictions than RPG's spillover range

- $\quad$ Economies of scope supports providing two or more RPGs whose spillover ranges do not coincide

- Economies of learning may require oversized jurisdictions to augment the cumulative RPG provision

- Requisite subsidiarity-based institution (jurisdiction) may not exist

- Too costly to tailor jurisdictions to each subregional public good owing to the proliferation of jurisdictions

- Aggregator technologies (e.g., best-shot, better-shot, and threshold) may favor pooling efforts beyond requisite jurisdiction

- $\quad$ Aggregator technologies (e.g., weakest-link and weaker-link) may require that participants bolster capacity beyond the spillover range of the public good

- Requisite financing may require a jurisdiction beyond the good's range of benefit spillovers

$\mathrm{RPG}$ = regional public good

Source: Asian Development Bank (2018) 


\section{Case Studies in Asia}

This section discusses case studies relevant to the Asian region and shows the challenges and benefits of collective action through the provision of RPGs. The first case study discusses how the Boxing Day Tsunami in 2004 that affected multiple countries led to a regional approach in adopting an early warning system for disasters. While initial investments can be made by more affluent countries around the Indian Ocean, maintenance of the system requires greater collective action, especially for an event that occurs very rarely. The regional detection and warning system should also be complemented by national responses in averting disaster for communities at risk. The second case study discusses the regional arrangements taken among Pacific economies to prevent overfishing of tuna in the high seas through the monitoring of fishing vessels' location and limiting their time at sea. As new technologies and larger vessels may complicate matters, sometimes economies adopt second-best approaches over costly first-best means in managing common resources. The third case study on malaria highlights that control or reducing its incidence is a national public good, while its elimination to zero cases can be both a national and regional public good. Malaria poses a serious health risk in Asia, and its elimination can serve both a regional and global public good especially in sub-Saharan Africa. The case study also briefly discusses one of the regional efforts in the Greater Mekong Subregion (GMS) to overcome the negative health impacts of the ongoing COVID-19. The fourth case discusses the difficulties encountered in fostering cooperative management of the Mekong River Basin as it serves different uses for various countries. These uses are usually in conflict: while upstream nations use it for hydropower, this affects uses for agriculture and fisheries downstream. The GMS Economic Cooperation Program can be a good venue for addressing the conflicting interests in the Mekong River Basin.

\section{Early Warnings of Disasters}

The Boxing Day Tsunami of 2004 killed over 230,000 people. Had there been an early warning system, many thousands of people would have been saved. For example, the tsunami hit Sri Lanka about 2 hours after the initial earthquake located about 1,600 kilometers away. In Sri Lanka alone, perhaps 30,000 people died for lack of warning. The "early warning" includes detection of an impending disaster and the reporting of this knowledge. Detection is an RPG if the information is disseminated throughout the region without restriction. Investment in a system for detection and reporting, and maintenance, is critical to whether knowledge of an impending disaster is reported.

A collective approach to establishing and maintaining early warning systems for disasters would be more beneficial. First, the cost of an integrated system would be below the aggregate cost of separate systems of equal coverage, not least because an integrated system can avoid duplicative components. Second, an integrated early warning system will generally be more effective than a collection of separate systems, as it will enable every member of the system to pick up additional signals, especially 
as some detection facilities will be under the jurisdiction of other states (seismometers on land and sea-level gauges within the exclusive economic zones of coastal states). It is very likely that the benefit to an individual country of supplying a sophisticated early warning system unilaterally could fall short of the cost, even as the benefit to all countries in a region of supplying a sophisticated, integrated early warning system could easily exceed the cost.

The Indian Ocean Tsunami Warning and Mitigation System was launched in 2011. Under this arrangement, Australia, India, and Indonesia are responsible for issuing warnings to member states. Table 4 and Figure 3 show the increase in investment for detection that has been made since the Boxing Day tsunami. Seismometers detect seismic waves that point to the creation of a tsunami. Sea-level gauges and tsunameters confirm the existence of a tsunami. Multiple sites of detection make prediction of a tsunami's path more precise.

\section{Table 4: Indian Ocean Tsunami Early Warning System, 2004 and 2014}

\begin{tabular}{|l|r|r|}
\hline Detection Equipment & 2004 & 2014 \\
\hline Broadband seismometers sharing data in near real-time & 13 & $>140$ \\
Coastal sea-level gauges sharing data in real-time & 4 & $>100$ \\
\hline Deep ocean tsunameters sharing data in near real-time & 0 & 9 \\
\hline
\end{tabular}

Source: Intergovernmental Oceanographic Commission of United Nations Educational, Scientific, and Cultural Organization (IOC-UNESCO) (2015).

Early warning of tropical cyclones is another regional public good. One regional system is the Typhoon Committee, which covers storms in the Western Pacific. Another is the Panel on Tropical Cyclones, responsible for the Bay of Bengal and the Arabian Sea.

After experiencing an event like the Boxing Day Tsunami, the first impulse is to put in place an early warning system. Investment is needed, but so is maintenance. Given that the system is integrated and that a tsunami of the scale of Boxing Day 2004 is rare, the countries may have less incentive to maintain it. Neglect of maintenance could lead to a system failure. One remedy is to integrate it with a larger system more regularly used for related hazards such as storm surges (Alverson 2005). ${ }^{3}$ Just as tsunamis can be triggered by underwater earthquakes, so storm surges can be caused by tropical cyclones far from shore. Many of the same investments, like tidal gauges, that detect a tsunami can also detect storm surges associated with tropical cyclones.

It is essential to have an international reporting system through official channels, involving one state reporting to others or a multilateral organization reporting to its member states. Another part of the system involves states communicating early warnings to communities at risk. It also involves states ensuring that such communities, having been given this information, know how to respond. These steps might be called communication and trained response. Communication and trained response are national public goods.

The RPG of detection and reporting and the national public good of communication and trained response are strong complements. Developing a regional early warning system is of little value if states lack the ability to communicate warnings to communities at risk. Similarly, the returns from

3 One regional system for tropical cyclones is the United Nations Economic and Social Commission for Asia and the Pacific (ESCAP)/World Meteorological Organization (WMO) Typhoon Committee, which covers storms in the Western Pacific. Another is the ESCAP/WMO Panel on Tropical Cyclones, responsible for the Bay of Bengal and the Arabian Sea. 


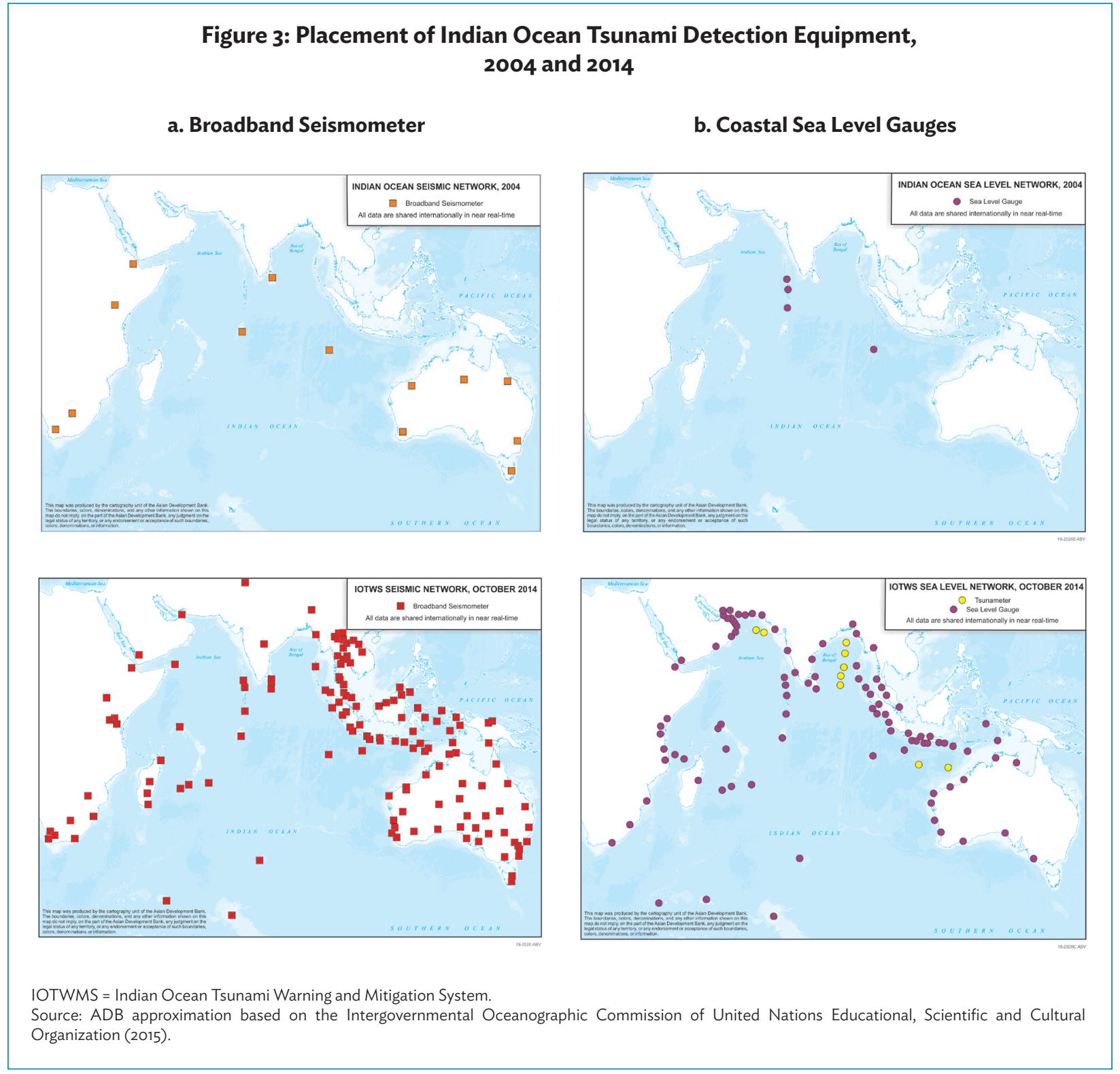

communicating warnings increase both with the timeliness and accuracy of the warnings and the ability and inclinations of communities to respond.

In terms of aggregation technology, the provision of early warning systems for disasters highlights the role of better-shot and weakest-link technologies. While detection and reporting at a regional level are led by Australia, India, and Indonesia, communication and trained responses are more national in scope. The latter calls for shoring up the capabilities of weakest-link economies in helping communities at risk which are national public goods. A regional early warning system is of little value if states lack the ability to communicate such warnings and respond to the threats to these communities. 


\section{Regional Fisheries Management}

Current property rights arrangements for the oceans are enshrined in customary international law and codified in the Law of the Sea Convention that gives every state a right to fish on the high seas. Coastal states have exclusive jurisdiction over fisheries up to 370 kilometers from shore. Fisheries located within the exclusive economic zone may be managed efficiently by the coastal state regulating access as a "sole owner." Overfishing is a problem only where the coastal state lacks either the ability or an interest in regulating access. Beyond the exclusive economic zones (EEZs), which include those for small island states and for archipelagic waters, are the high seas, where a regime of open access prevails. Some fisheries are entirely within the high seas, some overlap a multiple of EEZs, and some overlap both EEZs and the high seas. In these areas, where competition among states is likely to lead to overfishing and sometimes conflict, coastal states and distantwater fishing states cooperate to manage the fishery collectively, mainly through regional fishery management organizations.

A shared fishery requires aggregate efforts to preserve it because of the potential "tragedy of the commons." When a fishery is managed efficiently, every country fishing will earn a positive "rent" from it. And every country exploiting the resource will have an incentive to increase its harvest. Similarly, countries that had not exploited the resource will have an incentive to enter the fishery. This is the principal challenge to an international regime for managing a fishery: deterring states that are in the fishery from fishing excessively while deterring stares that are not in the fishery from entering.

Tuna are a particularly interesting and valuable fishery. They migrate widely, moving in and out of various EEZs besides traversing the high seas. As a general matter, the highly migratory nature of these fish makes tuna conservation a great challenge for international management. The western and central Pacific Ocean hosts the world's largest and most valuable tuna fishery, worth about $\$ 6$ billion per year (World Bank 2017). The main agreement that applies to this fishery is the Convention for the Conservation and Management of Highly Migratory Fish Stocks in the Western and Central Pacific Ocean, which came into force in 2004. This agreement established the Western and Central Pacific Fisheries Commission, the organization responsible for managing this regional fishery. Another major organization that serves a related purpose is the Pacific Islands Forum Fisheries Agency, which came into force in 1979 and was established by the South Pacific Fisheries Agency Convention. As a subgroup to the agency, the Parties to the Nauru Agreement (PNA) controls the world's largest sustainable purse seine tuna fishery. ${ }^{4}$

Signatories to the PNA have adopted two bold measures, one involving closure of high-seas areas that border the EEZs of these states and the other involving a vessel day scheme. The ban, adopted in 2008, applies to "high-sea pockets" which are next to the EEZs (Figure 4). Compliance with the ban is monitored by the requirement that all licensed vessels fishing in the EEZs of PNA member states carry radio transponders which reveal their coordinates at all times. In this ocean, it is not profitable to fish within these high-seas pockets only, and so states with expansive EEZs can make fishing within their waters conditional on vessels not fishing within these high-seas pockets. In other oceans, a ban on high-seas fishing could not be orchestrated as easily.

$4 \quad$ The Forum Fisheries Agency (FFA) has 17 Pacific Island members: Australia, the Cook Islands, the Federated States of Micronesia, Fiji, Kiribati, the Marshall Islands, Nauru, New Zealand, Niue, Palau, Papua New Guinea, Samoa, Solomon Islands, Tokelau, Tonga, Tuvalu, and Vanuatu. FFA is an advisory body providing expertise, technical assistance, and other support to its members who make sovereign decisions about their tuna resources and participate in regional decision-making on tuna management through agencies such as the Western and Central Pacific Fisheries Commission. (Source: https://www.ffa.int/about) 
A first-best solution would be putting a fishery under the control of a sole owner, involving many parties implementing the full cooperative outcome. Closing these high-sea pockets could be a good move for PNA members, as it increases their control over the fishery. However, the restrictions may also increase the cost of fishing. Comprehensive management of the entire territory would likely improve matters.

The vessel day scheme, adopted by the PNA in 2012, sets a total number of days in which vessels may fish within PNA waters, a value chosen to satisfy conservation and management objectives determined by the Western and Central Pacific Fisheries Commission. The current approach contrasts with the previous system, under which vessel numbers were fixed, with the allocations going directly to the vessels rather than the PNA members (Yeeting et al. 2016).

Under the vessel day scheme, however, the problem of overfishing remained because of the adoption of new technologies like fish aggregating devices and the use of larger vessels. Purse seiners increased their catch of big-eye tuna, causing this species to be overfished. A limit on harvests would be more effective but also harder to implement because it would be more difficult to monitor catches than to monitor vessel days. Moreover, it does not tackle the incentives for other fisheries commission members to free-ride by setting higher limits in their waters. At the same time, the new scheme increased access fees as a share of the total value of landed fish, rising from 3\% to $6 \%$ under the old system to $14 \%$ under the new scheme (Yeeting et al. 2016).

Figure 4: High-Seas Areas Closed to Fishing by the Parties to Nauru Agreement

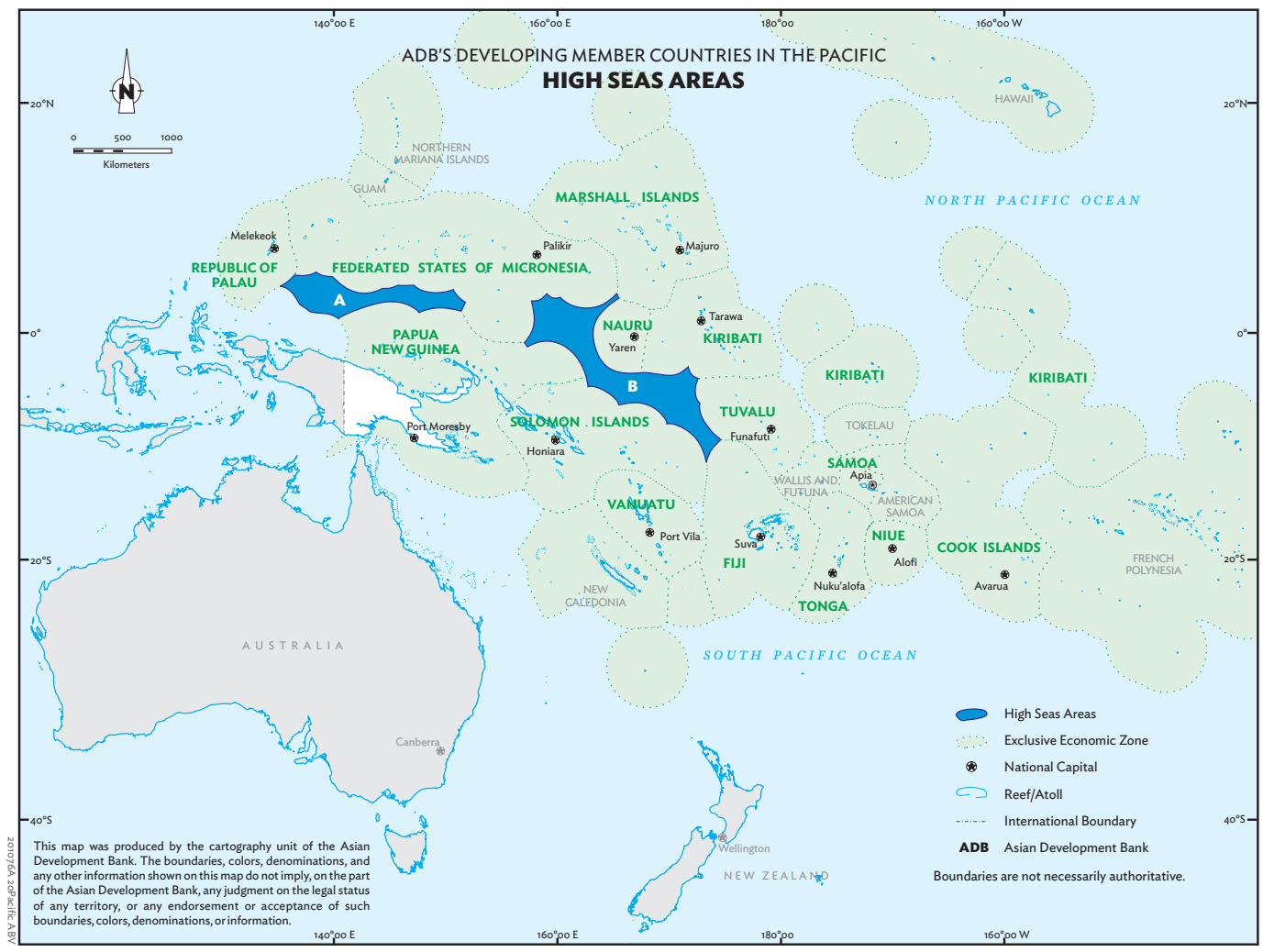

Note: Areas A and B are the sea pockets with the ban on fishing for the members of the Parties of Nauru Agreement as of August 2018. Source: ADB approximation based on Western and Central Pacific Fisheries Commission (2016). 


\section{Malaria Control and Elimination}

Individuals and households have incentives to avoid being infected with malaria by using bed nets, spraying indoor walls with insecticide, by modifying the housing stock, and by changing behavior. Communities also have incentives to limit malaria by using larvicides and eliminating breeding areas for mosquito vectors. "Control" is a public health intervention that reduces the number of cases of malaria in a well-defined area for a certain period. "Elimination" is a control that reduces cases to zero. Control is normally undertaken at the national level. Elimination is a national or regional public good. Once the parasite is removed from a locale, residents need not fear becoming infected, nor do they have to guard against infection. No one living where malaria has been eliminated can be excluded from enjoying this benefit, and nor does any such person's enjoyment of this good affect anyone else's enjoyment.

Malaria elimination is a threshold public good. To eliminate the disease, the life cycle of the parasite must be broken, which means that infections in mosquitoes and humans must be reduced to zero. This can be done by various means, including the application of larvicides in mosquito breeding sites, indoor spraying of walls with insecticide, the use of insecticide treated bed nets, and the use of antimalarial drugs. These means must be used in tandem and in great enough volume to drive transmission to zero. Any less, and malaria will persist. Any more, and resources will be wasted.

Malaria elimination in Sri Lanka is a classic national public good. In 1935, over 1.5 million cases resulted in 80,000 deaths. In the global effort to eradicate malaria in the 1950s, Sri Lanka reduced cases to just 17 in 1963. However, malaria rebounded. By 1970, there were 1 million cases. ${ }^{5}$ Sri Lanka attempted to eliminate malaria within the global eradication effort. Its failure is symbolic of the global failure to eradicate malaria. Sri Lanka will benefit from malaria controls made elsewhere, just as other countries will benefit from Sri Lanka's success in eliminating malaria. However, on an island like Sri Lanka, these benefits may be quite small.

Control and elimination in more continental areas is a different matter. Here, the flow of malaria (carried both by infected mosquitoes and infected humans) can be so great that it may never pay or even be feasible for a country to eliminate malaria unilaterally. Malaria elimination requires a regional approach. Providing poor countries with financing and capacity building helps the elimination process, which makes regional elimination a weakest-link RPG.

At the 2014 East Asia Summit, 18 leaders declared the goal of eliminating malaria from the region by $2030 .{ }^{6}$ In a continental context, it may not pay any country in a region to eliminate malaria unilaterally. Provision of the public good is likely to succeed if all countries work together: once each country is assured that others in the region will eliminate malaria, each has an incentive to make efforts to do the same.

An example of this kind of provision is the Regional Malaria and Other Communicable Disease Threats Trust Fund, which ADB set up in 2013 "to support developing member countries to develop multi-country, cross-border and multisector responses to urgent malaria and other communicable disease issues" (ADB 2015). A trust fund is needed when the poorest countries in a region lack the

WHO South-East Asia. http://www.searo.who.int/srilanka/areas/malaria/sri-lanka-defeats-malaria/en/

6 ADB members include Brunei Darussalam, Cambodia, India, Indonesia, the Lao People's Democratic Republic, Malaysia, Myanmar, the People's Republic of China, the Philippines, the Republic of Korea, Singapore, Thailand, and Viet Nam. (Source: http://aplma.org/upload/resource/Meeting/gth_EAS_chairman_statement.pdf) 
incentive or the capability and resources to eliminate malaria inside their borders. A key component for eradicating smallpox was for financing and the provision of technical assistance in poor countries. The same is true of ongoing efforts to eradicate polio and Guinea worm disease.

An investment case for elimination also exists if the actions needed to keep malaria out, or to prevent its spread, are substantially different and cheaper than the actions needed to eliminate locally acquired malaria in the first place. Moonen et al. (2009) report that for Hainan Island in the People's Republic of China (PRC), the cost of maintaining high control is $\$ 2.9$ million a year, but the annual cost of maintaining elimination would be only about $\$ 1.6$ million. Achieving elimination would be costly and take several years, but as the post-elimination costs are much lower than for high control, the investment in elimination could easily pay off.

Malaria poses a serious health risk in Asia (Table 5). It can also be considered a global public good, as elimination in Asia will have consequences for countries outside of the region. While fewer than 5,000 people-most of them adult males-die of malaria every year in this region, over 400,000 children die of malaria in Africa (WHO 2017). The Greater Mekong Subregion (GMS) has long been a crucible for antimalarial drug resistance (Roberts 2016). ${ }^{7}$ If resistance were eliminated there, malaria would be much less likely to develop globally, providing a benefit to the whole world, subSaharan Africa especially. Allocating funding for regional health security can contribute to global elimination. In this regard, the Strategy for Malaria Elimination in the GMS (2015-2030), which was endorsed by the World Health Assembly in May 2015, aims to supply this global public good by eliminating malaria throughout the GMS by 2030 , at an estimated cost of about $\$ 3$ billion (WHO 2015).

As to the latest, ongoing RPG provision for regional health security, ADB's GMS Health Security Project is one of the regional efforts to address the COVID-19 pandemic. The project started as a $\$ 132$ million project in 2016 to help strengthen the health systems of Cambodia, the Lao People's Democratic Republic, Myanmar, and Viet Nam against communicable diseases (ADB 2018). These countries are highly vulnerable to disease outbreaks such as the severe acute respiratory syndrome (SARS), avian influenza, malaria, dengue, and coronavirus due to weak health systems and high trading activity and mobility of people across borders (ADB 2016).

The regional project aims to strengthen these countries' surveillance and outbreak response, laboratory quality and biosafety, and health services access. Laboratories and services at district hospitals are also being strengthened at border areas and economic corridors where outbreaks are likely to occur to improve infection control and prevention. To mitigate adverse health effects from the COVID-19 pandemic, the regional project with additional financing is being utilized to help the countries immediately procure essential items such as personal protective equipment, laboratory equipment, testing kits, medical devices, and ambulances. They also include supplies and training of health-care workers for lab testing, contact tracing, and care for COVID-19 patients.

\footnotetext{
Resistance to choloroquine emerged here in the 1950s. Resistance to sulfadoxine-pyrimethamine surfaced here in the 1960s. Mefloquine-resistant strains emerged in the 1970s. In 2008-2009, resistance to artemisinin was detected in the same area. Later still, resistance to piperaquine, a drug often used in combination with artemisinin, acquired resistance here.
} 
Table 5: Malaria Risk in Asia and the Pacific, 2010 and 2016

\begin{tabular}{|c|c|c|c|c|c|c|}
\hline \multirow[b]{2}{*}{ Country } & \multicolumn{3}{|c|}{2010} & \multicolumn{3}{|c|}{2016} \\
\hline & $\begin{array}{l}\text { Population } \\
\text { at Risk }\end{array}$ & Cases $^{\mathrm{a}}$ & Deaths ${ }^{a}$ & $\begin{array}{c}\text { Population } \\
\text { at Risk }\end{array}$ & Cases $^{\mathrm{a}}$ & Deaths $\mathrm{s}^{\mathrm{a}}$ \\
\hline Afghanistan & $15,022,161$ & 556,000 & 270 & $18,074,695$ & 348,000 & 200 \\
\hline Armenia & 0 & & & 0 & & \\
\hline Azerbaijan & 103,873 & & & 111,842 & & \\
\hline Bangladesh & $9,140,814$ & 6,000 & $\leq 100$ & $9,789,803$ & 79,300 & 190 \\
\hline Bhutan & 316,526 & $\leq 100$ & 0 & 347,023 & 400 & $\leq 10$ \\
\hline Cambodia & $8,502,630$ & 83,300 & 140 & $9,366,419$ & 175,000 & 300 \\
\hline PRC & $286,014,749$ & $\leq 10$ & 0 & $295,239,160$ & 5,000 & $\leq 100$ \\
\hline Georgia & 21,158 & & & 19,627 & & \\
\hline India & $649,780,540$ & $13,170,000$ & 23,990 & $698,971,796$ & $21,090,000$ & 32,600 \\
\hline Indonesia & $129,015,921$ & $1,281,000$ & 2,200 & $138,905,980$ & $2,715,000$ & 4,000 \\
\hline Kyrgyz Republic & 2,158 & & & 2,370 & & \\
\hline Lao PDR & $3,250,162$ & 27,390 & $\leq 100$ & $3,516,615$ & 51,000 & 120 \\
\hline Malaysia & 983,931 & 270 & $\leq 10$ & $1,091,554$ & 5,000 & $\leq 100$ \\
\hline Myanmar & $18,890,792$ & 142,600 & 240 & $19,918,767$ & $2,155,000$ & 4,000 \\
\hline Nepal & $4,628,293$ & 4,000 & $\leq 10$ & $4,963,923$ & 43,400 & $\leq 100$ \\
\hline Pakistan & $108,499,981$ & $1,307,000$ & 1,100 & $122,904,269$ & $1,645,000$ & 1,900 \\
\hline $\begin{array}{l}\text { Papua New } \\
\text { Guinea }\end{array}$ & $6,895,001$ & $1,407,000$ & 3,000 & $7,842,443$ & $1,342,000$ & 2,900 \\
\hline Philippines & $30,409,133$ & 16,630 & $\leq 100$ & $33,521,730$ & 53,200 & 110 \\
\hline $\begin{array}{l}\text { Republic of } \\
\text { Korea }\end{array}$ & $1,734,350$ & 600 & 0 & $1,777,717$ & 1,300 & $\leq 10$ \\
\hline Solomon Islands & 522,518 & 86,000 & 110 & 593,432 & 95,900 & 170 \\
\hline Sri Lanka & $2,322,811$ & & & $2,391,826$ & & \\
\hline Tajikistan & $1,406,059$ & 0 & 0 & $1,607,231$ & 130 & 0 \\
\hline Thailand & $7,120,773$ & 11,520 & $\leq 100$ & $7,296,090$ & 32,500 & $\leq 100$ \\
\hline Timor-Leste & 132,565 & 140 & 0 & 151,571 & 113,300 & 220 \\
\hline Turkmenistan & 0 & & & 0 & & \\
\hline Uzbekistan & 28,606 & & & 31,447 & & \\
\hline Vanuatu & 220,861 & 4,000 & $\leq 10$ & 252,727 & 13,780 & $\leq 100$ \\
\hline Viet Nam & $35,608,591$ & 6,000 & $\leq 10$ & $38,062,347$ & 25,460 & $\leq 100$ \\
\hline
\end{tabular}

Lao PDR = Lao People's Democratic Republic, PRC = People's Republic of China.

a These data are midpoints of ranges. For example, for Afghanistan in 2010, the range corresponding to the midpoint, 348,000, is 207,600 to 534,000 for cases; and for the midpoint 200, the range is from 100 to 400 for deaths.

Source: World Malaria Report 2017, Annex 3 F.a and F.b., pp. 120-133. Data not available for Brunei Darussalam; the Cook Islands; Fiji; Hong Kong, China; Kazakhstan; Kiribati; Maldives; the Marshall Islands; the Federated States of Micronesia; Mongolia; Nauru; Palau; Samoa; Singapore; Taipei,China; Tonga; and Tuvalu.

\section{Cooperative Management of the Mekong River Basin}

River basin management is often referred to as an RPG because of its inherent regional use as a shared resource. Several Asian countries overlap with many transboundary river basins (Table 6). The Mekong River is shared by six countries and crosses some of the poorest parts of Asia. It starts in the Tibetan highlands of the PRC, flows through Yunnan Province, and then into Myanmar, the Lao People's Democratic Republic, Thailand, Cambodia, and Viet Nam. The Mekong River serves different purposes for different countries. The PRC and the Lao People's 
Democratic Republic regard the river primarily as a resource for hydropower development and navigation. Thailand values it for irrigation, Cambodia for fisheries, and Viet Nam for agriculture (Pham Do and Dinar 2014). Use of the Mekong River thus affects flood control, water availability for agriculture, water quality, fisheries, hydropower, navigation, and ecosystem conservationuses that are frequently in conflict. For example, hydropower development upstream can disrupt agriculture and fisheries stocks downstream. Collective action needs to reconcile not only the river's many alternative uses, but also the interests of the different states as regards these uses.

Table 6: International River Basins in Asia

\begin{tabular}{|c|c|c|c|c|c|c|c|}
\hline Basin & $\begin{array}{l}\text { Area } \\
\left(\mathrm{km}^{2}\right)\end{array}$ & Countries & $\begin{array}{c}\text { Share } \\
(\%)\end{array}$ & Basin & $\begin{array}{l}\text { Area } \\
\left(\mathrm{km}^{2}\right)\end{array}$ & Countries & $\begin{array}{c}\text { Share } \\
(\%)\end{array}$ \\
\hline \multirow[t]{3}{*}{ Amur } & \multirow[t]{3}{*}{$1,884,000$} & Russian Federation & 53 & \multirow[t]{3}{*}{ Hari/Harirud } & \multirow[t]{3}{*}{92,600} & Afghanistan & 44 \\
\hline & & PRC & 45 & & & Iran & 38 \\
\hline & & Mongolia & 2 & & & Turkmenistan & 18 \\
\hline \multirow[t]{4}{*}{ Aral Sea } & \multirow[t]{4}{*}{$1,319,900$} & Kazakhstan & 70 & \multirow[t]{3}{*}{ Helmand } & \multirow[t]{3}{*}{345,200} & Afghanistan & 82 \\
\hline & & Uzbekistan & 18 & & & Iran & 14 \\
\hline & & Kyrgyz Republic & 10 & & & Pakistan & 4 \\
\hline & & Tajikistan & 1 & \multirow[t]{2}{*}{ His/Bei Jang } & \multirow[t]{2}{*}{361,500} & PRC & 97 \\
\hline \multirow[t]{2}{*}{ Astara Chay } & \multirow[t]{2}{*}{560} & Iran & 81 & & & Viet Nam & 3 \\
\hline & & Azerbaijan & 19 & \multirow[t]{3}{*}{ III/Kunes He } & \multirow[t]{3}{*}{161,200} & Kazakhstan & 60 \\
\hline \multirow[t]{2}{*}{ Atrak } & \multirow[t]{2}{*}{34,200} & Iran & 69 & & & PRC & 34 \\
\hline & & Turkmenistan & 31 & & & Kyrgyz Republic & 5 \\
\hline \multirow[t]{2}{*}{ Bangau } & \multirow[t]{2}{*}{430} & Malaysia & 53 & \multirow[t]{5}{*}{ Indus } & \multirow[t]{5}{*}{$1,086,000$} & Pakistan & 56 \\
\hline & & Brunei Darussalam & 46 & & & India & 26 \\
\hline \multirow[t]{2}{*}{ Beilun } & \multirow[t]{2}{*}{960} & PRC & 74 & & & PRC & 34 \\
\hline & & Viet Nam & 26 & & & Afghanistan & 7 \\
\hline \multirow{2}{*}{$\mathrm{Ca} /$ Song-Koi } & \multirow{2}{*}{33,800} & Viet Nam & 58 & & & Disputed & 1 \\
\hline & & Lao PDR & 42 & \multirow[t]{3}{*}{ Ayeyarwady } & \multirow[t]{3}{*}{404,100} & Myanmar & 91 \\
\hline Coruh & 20,700 & Turkey & 91 & & & PRC & 5 \\
\hline & & Georgia & 9 & & & India & 4 \\
\hline Dasht & 31,800 & Pakistan & 79 & Kaladan & 30,500 & Myanmar & 74 \\
\hline & & Iran & 21 & & & India & 24 \\
\hline Fenney & 2,800 & India & 66 & Kamafauli & 15,000 & Bangladesh & 75 \\
\hline & & Bangladesh & 34 & & & India & 25 \\
\hline Fly & 64,600 & Papua New & 93 & Kowl- & 40,100 & Iran & 67 \\
\hline & & Guinea & & E-Namaksar & & Afghanistan & 33 \\
\hline & & Indonesia & 7 & Lake Ubsa-Nur & 74,800 & Mongolia & 70 \\
\hline Ganges- & $1,675,700$ & India & 58 & & & Russian Federation & 30 \\
\hline Brahmaputra- & & PRC & 19 & Ma & 24,600 & Viet Nam & 68 \\
\hline Meghna & & Nepal & 9 & & & Lao PDR & 32 \\
\hline & & Bangladesh & 7 & Mekong & 780,300 & Lao PDR & 25 \\
\hline & & Bhutan & 2 & & & Thailand & 25 \\
\hline & & Disputed & 4 & & & PRC & 22 \\
\hline Golok & 1,800 & Thailand & 58 & & & Cambodia & 20 \\
\hline & & Malaysia & 42 & & & Viet Nam & 4 \\
\hline Han & 35,300 & Republic of Korea & 71 & & & Myanmar & 4 \\
\hline & & DPRK & 29 & Merauke & 6,500 & Indonesia & 61 \\
\hline Har US Nur & 197,800 & Mongolia & 99 & & & Papua New & 39 \\
\hline & & Russian Federation & 1 & & & Guinea & \\
\hline
\end{tabular}


Table 2 continued

\begin{tabular}{|c|c|c|c|c|c|c|c|}
\hline Basin & $\begin{array}{l}\text { Area } \\
\left(\mathrm{km}^{2}\right)\end{array}$ & Countries & $\begin{array}{c}\text { Share } \\
(\%)\end{array}$ & Basin & $\begin{array}{l}\text { Area } \\
\left(\mathrm{km}^{2}\right)\end{array}$ & Countries & $\begin{array}{c}\text { Share } \\
(\%)\end{array}$ \\
\hline \multirow[t]{2}{*}{ Murgab } & 60,900 & Afghanistan & 60 & \multirow[t]{3}{*}{ Sepik } & \multirow[t]{3}{*}{73,400} & Papua New & 97 \\
\hline & & Turkmenistan & 40 & & & Guinea & \\
\hline $\mathrm{Ob}$ & $2,734,800$ & Russian Federation & 77 & & & Indonesia & 3 \\
\hline \multirow[t]{2}{*}{ Oral } & 260,400 & Kazakhstan & 55 & \multirow{2}{*}{$\begin{array}{l}\text { Song Vam Co } \\
\text { Dong }\end{array}$} & \multirow[t]{2}{*}{15,300} & Viet Nam & 50 \\
\hline & & Russian Federation & 45 & & & Cambodia & 50 \\
\hline \multirow[t]{2}{*}{ Pakchan } & 2,700 & Thailand & 60 & \multirow[t]{2}{*}{ Sujfun } & \multirow[t]{2}{*}{16,800} & PRC & 58 \\
\hline & & Myanmar & 39 & & & Russian Federation & 42 \\
\hline \multirow[t]{2}{*}{ Pandaruan } & 810 & Brunei Darussalam & 50 & \multirow[t]{3}{*}{ Tami } & \multirow[t]{3}{*}{89,900} & Indonesia & 98 \\
\hline & & Malaysia & 50 & & & Papua New & 2 \\
\hline \multirow[t]{2}{*}{ Pun-Lun-To } & 88,400 & PRC & 86 & & & Guinea & \\
\hline & & Mongolia & 14 & \multirow[t]{3}{*}{ Tarim } & \multirow[t]{3}{*}{950,200} & PRC & 95 \\
\hline \multirow[t]{3}{*}{ Red/Song Hong } & \multirow[t]{3}{*}{164,600} & PRC & 51 & & & Kyrgyz Republic & 3 \\
\hline & & Viet Nam & 48 & & & Disputed & 2 \\
\hline & & Lao PDR & 1 & \multirow[t]{3}{*}{ Tumen } & \multirow[t]{3}{*}{33,000} & PRC & 69 \\
\hline \multirow{2}{*}{$\begin{array}{l}\text { Saigon/Song } \\
\text { Nha Be }\end{array}$} & 29,400 & Viet Nam & 99 & & & DPRK & 31 \\
\hline & & Cambodia & 1 & & & Russian Federation & 1 \\
\hline \multirow[t]{3}{*}{ Salween } & 244,100 & PRC & 52 & \multirow[t]{2}{*}{ Yalu } & \multirow[t]{2}{*}{63,000} & DPRK & 50 \\
\hline & & Myanmar & 44 & & & PRC & 50 \\
\hline & & Thailand & 4 & \multirow[t]{2}{*}{ Yenisey/Jenisej } & \multirow[t]{2}{*}{$2,497,600$} & Russian Federation & 87 \\
\hline \multirow[t]{2}{*}{ Sembakung } & 15,300 & Indonesia & 54 & & & Mongolia & 13 \\
\hline & & Malaysia & 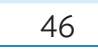 & & & & \\
\hline
\end{tabular}

DPRK = Democratic People's Republic of Korea, $\mathrm{km}^{2}=$ square kilometer, Lao PDR $=$ Lao People's Democratic Republic, PRC $=$ People's Republic of China. Notes: Excludes all countries with shares less than $1 \%$. Shares are calculated as $1 \%$ of area in $\mathrm{km}^{2}$.

Source: Wolf et al. (1999).

A fruitful approach is for the parties to agree on the best use of the river basin as a whole, and for claims to individual rights to be addressed using the side-payments and cost-sharing arrangements. A review of experience in transboundary river basin management worldwide shows that the bargains reached depend on the circumstances (Dinar 2006). When a river forms a border between two states, the costs of joint development are typically shared equally. When one state is upstream and another downstream, side payments are typical, but which state pays depends on income levels. When an upstream state wishes to develop its portion of a river to the detriment of its downstream neighbor, the upstream state tends to make a payment to the downstream state when the upstream state is richer. When the upstream state is poorer than the downstream state, the downstream state may pay the upstream state to modify its plans.

One of the difficulties for collective action is that the allocation of property rights is often disputed. Upstream states have a geographic advantage and may claim a right to develop "their" resources as they please. However, international law also recognizes that downstream states have a right not be harmed by upstream development. International law favors "equitable utilization" of transboundary rivers, but how this outcome is determined is for the parties to negotiate (Barrett 2003). Side payments are a simple matter when property rights are not in dispute. However, side payments may not suffice to secure an efficient outcome when property rights are disputed.

Management of the Mekong River basin has more room for improvement by strengthening cooperation and partnerships between related organizations. In the Mekong River basin, the lower basin countries, the Lao People's Democratic Republic, Thailand, Cambodia, and Viet Nam, 
cooperate through the Mekong River Commission, while the upstream countries, the PRC and Myanmar, are "dialogue partners." Even among lower basin countries, the commission has struggled to address a dispute over use (Pham Do and Dinar 2014). As such, the GMS Economic Cooperation Program, established with ADB assistance in 1992, might be a more appropriate institution for management of the river basin in partnership with the Mekong River Commission. It can serve as a forum for linking a broader set of issues relevant to regional sustainable development since its membership includes all GMS states. 


\section{Case Studies in Europe}

Case studies in Europe highlight the various regional arrangements taken to address common interests. The first case study discusses how the goal of exchange rate stability led to the push toward monetary integration by the European Union (EU). Periodic financial crises created supranational institutions to safeguard financial integration and enhance stability. The second case study discusses energy market integration to enhance access to energy and ensure security of supply. This has resulted in common legislation to liberalize markets and harmonize regulations, and funding mechanisms to support hardware infrastructure in the region. The third case study on mitigating overpricing in international mobile roaming shows that a regional approach was also necessary as no single national regulator could address issues in both the home and visited networks.

\section{Financial Stability in the European Union}

Europe's historical quest for exchange rate stability is the root of European monetary integration. An urgent real push toward integration came with the crisis of the Bretton Woods international monetary arrangements, which collapsed in 1971 with the suspension of dollar convertibility. Exchange rates were a concern to countries that were highly open and traded a lot with each other-like the European countries. Moreover, European countries had a further reason for favoring exchange rate stability as an RPG, as volatility would have increased the cost and complexity of administering the European Common Agricultural Policy (McNamara 1998; Eichengreen 2007).

The 1992 Maastricht Treaty attempted to strike a balance between economists' and monetarists' views of European monetary integration, by laying out convergence criteria that prospective members would have to meet. ${ }^{8}$ In May 1998, 11 countries achieved this and formed the nucleus of the monetary union, which has expanded to 19 members. On 1 January 1999, the euro was introduced and the Eurosystem - the European Central Bank and the national central banks of countries in the European Economic and Monetary Union-took over responsibility for monetary policy. While more stable than previous arrangements (McNamara 1998), the European Monetary System still suffered the typical weakness of fixed exchange rate systems, i.e., no institution could force central banks to intervene to support currencies of other countries (Table 7).

8 Inflation rate should be no more than 1.5\% higher than the average of the inflation rates in the three EU member states with the lowest inflation; government deficit of no more than $3 \%$ of gross domestic product (GDP); public debt of no more than $60 \%$ of GDP; exchange rate should be within a $\pm 15 \%$ range from an unchanged central rate stable interest rates; and 10 -year government bonds shall be no more than $2.0 \%$ higher, than the average of the similar 10-year government bond yields in the three EU member states with the lowest inflation. 


\section{Table 7: Road to Currency Unification}

\begin{tabular}{|l|l|}
\hline 1970 & $\begin{array}{l}\text { Werner Report: Outlines a three-stage plan aimed at creating EMU by } 1980 \\
\text { (implementation will be delayed by the oil crises). }\end{array}$ \\
1979 & $\begin{array}{l}\text { Exchange Rate Mechanism (ERM): EEC countries agree to set up the ERM in order to reduce } \\
\text { volatility between European currencies, by setting bands of fluctuation. Great Britain will only } \\
\text { join in 1990. }\end{array}$ \\
1986 & $\begin{array}{l}\text { Single European Act: Major revision of the Treaty of Rome. EEC countries agree to create } \\
\text { a single market within the community by } 1992 .\end{array}$ \\
1992 & $\begin{array}{l}\text { Maastricht Treaty: Introduces the euro as a common currency and limits government deficits } \\
\text { and public debt levels to 3\% and 60\% of GDP, respectively. 1992/1993 also saw tensions } \\
\text { on the ERM, including the forced withdrawal of the pound sterling ("black Wednesday"). }\end{array}$ \\
1994 & $\begin{array}{l}\text { Stage } \mathbf{2} \text { of EMU: Establishes the European Monetary Institute, embryo of today's ECB. } \\
1997\end{array}$ \\
1998 & $\begin{array}{l}\text { Stability and Growth Pact, aimed at enforcing Maastricht rules. } \\
\text { ECB established in Frankfurt. }\end{array}$ \\
1999 & The euro is officially born on $\mathbf{1}$ January, currencies are irrevocably fixed. \\
\hline
\end{tabular}

$\mathrm{ECB}=$ European Central Bank, EEC $=$ European Economic Community, EMU $=$ Economic and Monetary Union, GDP $=$ gross domestic product. Source: Fredriksson, Marcus, Merler, Tagliapietra, and Wolff (2018)

The euro crisis proved that the original design of the monetary union was flawed. The crisis revealed that the monetary union failed to construct common institutions that would safeguard European financial integration. The single currency had a huge impact on financial flows in the euro area in two ways. The convergence of short and long-term yields coupled with persistent divergences of inflation rates led to marked divergences in real interest rates. Low interest rates in "periphery" countries led to a boom of private indebtedness and large current account imbalances within the monetary union as credit access expanded euro-wide compared to previous countrywide availability. Capital flow movements revealed greater volatility when these suddenly stopped and reversed during the euro crisis, exposing an underlying structural economic divergence that was difficult to sustain.

The crisis also exposed another shortcoming of monetary union. That is the failure to construct common institutions that would safeguard European financial integration. For instance, the euro area lacked the tools to prevent macroeconomic imbalances and financial imbalances from occurringi.e., strict and uniform microprudential banking supervision (Claeys 2017). Efforts at regulatory harmonization left supervision to an exclusively national level, even during monetary union in 1999. A complementary step in the form of a banking union was thus taken following the euro area crisis to improve regional financial stability. Three European supervisory authorities were set up to ensure closer cooperation and better exchange of information between national supervisors, and-by preparing uniform standards and ensuring supervisory convergence and coordination-to shape the development of a "single rulebook" applicable to all EU countries.

In 2009, the report from the European Commission-appointed "de Larosière group" concluded that the supervisory framework needed to be strengthened. It recommended creating the three supervisory authorities: one each for the banking sector, the securities sector, and for the insurance and occupational pensions sector. ${ }^{9}$ The de Larosière Report also recommended establishing a European Systemic Risk Board to monitor macroprudential risk (but without active macroprudential powers). The bolder institutional development was the establishment of the European banking union for euro area countries, triggered by the self-reinforcing negative feedback loops between banks

$9 \quad$ European Banking Authority, European Securities and Markets Authority, and European Insurance and Occupational Pensions Authority. 
and sovereigns that became the characteristic feature of the euro crisis. The European Council of 28-29 June 2012 agreed to shift bank supervisory authority from the national to the European level, delegating it to the Single Supervisory Mechanism within the European Central Bank (Table 8).

\section{Table 8: Selected Milestones of Financial Regulation Reform in Europe}

\begin{tabular}{|c|c|}
\hline 2007 & Risk-based prudential and solvency rules for insurers ('Solvency II'). \\
\hline 2008 & $\begin{array}{l}\text { First set of rules on credit rating agencies. Amended in } 2011 \text { to take into account } \\
\text { the creation of the European Securities and Markets Authority. Further amendment in } 2013 .\end{array}$ \\
\hline 2009 & Directive on Hedge Funds and Private Equity ('AIFMD'); Capital Requirement Directive III. \\
\hline 2009 & $\begin{array}{l}\text { Establishment of the European Supervisory Authorities and the European Systemic Risk } \\
\text { Board regulations. }\end{array}$ \\
\hline 2010 & $\begin{array}{l}\text { Revision of the Directive on Deposit Guarantee Schemes; European Market Infrastructure } \\
\text { Regulation; Regulation on Short-Selling and Credit Default Swap; Creation of the Single Euro } \\
\text { Payments Area ('SEPA'). }\end{array}$ \\
\hline 2011 & $\begin{array}{l}\text { New European supervisory framework for insurers ('Omnibus II'); Single rule book of } \\
\text { prudential requirements for banks capital, liquidity and leverage + stricter rules on } \\
\text { remuneration and improved transparency ('CRD IV / CRR'); Enhanced framework } \\
\text { for securities markets ('MIFID/R'); } \\
\text { Enhanced framework to prevent market abuse ('MAD/R'); Enhanced transparency rules, } \\
\text { Enhanced framework for audit sector. }\end{array}$ \\
\hline 2012 & $\begin{array}{l}\text { Improved investor information for complex financial products ('PRIPS'); Strengthened rules } \\
\text { on the sale of insurance products ('IMD'); Safer rules for retail investment funds ('UCITS'); } \\
\text { Bank Recovery and Resolution Directive. }\end{array}$ \\
\hline $2012 / 6$ & $\begin{array}{l}\text { The European Council decide to assign supervisory tasks to the European Central Bank (ECB) } \\
\text { within a Single Supervisory Mechanism (SSM). }\end{array}$ \\
\hline $2012 / 9$ & $\begin{array}{l}\text { European Commission presents draft regulations, which assign specific supervisory tasks } \\
\text { to the ECB (SSM regulation) and align the role and responsibilities of the European Banking } \\
\text { Authority with the new framework for banking supervision. }\end{array}$ \\
\hline 2013 & $\begin{array}{l}\text { Strengthened regime on anti-money laundering; Nonfinancial reporting for companies; } \\
\text { Access to basic bank account / transparency of fees / switching of bank accounts; Creation } \\
\text { of European long-term investment funds; Regulation of financial benchmarks } \\
\text { (such as LIBOR and EURIBOR); Shadow banking, including money market funds. }\end{array}$ \\
\hline $2013 / 10$ & ECB starts comprehensive assessment of banks. \\
\hline $2013 / 11$ & SSM regulation enters into force. \\
\hline 2014 & Single Resolution Mechanism Regulation. \\
\hline 2016/01 & Single Resolution Board becomes operational. \\
\hline
\end{tabular}

EURIBOR = Euro interbank offered rate, LIBOR = London interbank offered rate.

Source: Fredriksson, Marcus, Merler, Tagliapietra, and Wolff (2018).

Overall, national supervisors would have little incentive to internalize the cross-border effects of their domestic decisions and could be prone to capture by local politics. A supranational supervisor like the European Central Bank is better placed to oversee the transnational dimension of domestic policy, and to identify the potential risk for the euro area, while being less prone to regulatory capture. An important aspect of this reform is that it clearly acknowledged that risk to financial stability is made of different components (microprudential requirements and supervision, but also a macroprudential component) and that its aggregate and cross-border aspect is especially important in a closely integrated regional context. The path toward regional regulatory and supervisory integration in Europe carries an important lesson for observers elsewhere. It shows that to safeguard the economic outcomes, the pursuit of closer monetary and financial integration cannot be disjointed from an appropriate regional institutional setting. 
In pursuing financial stability, summation aggregation technology was adopted to secure exchange rate stability. This evolved into weakest-link and best-shot technologies. Financial assistance and capacity building for troubled economies came into play during the euro crisis, highlighting the role of weakest-link technologies. Surveillance mechanisms also emerged to prevent financial contagion. The example set by advanced economies on the design and adoption of sound macroeconomic policies informed the setup of financial institutions, underlying the role of best-shot technologies.

\section{Integrated Energy Market}

For over 60 years, EU countries have coordinated their national energy policies to guarantee their citizens access to energy at reasonable and stable prices, to maintain industrial competitiveness, to promote sustainable development, and to ensure security of energy supply. European efforts to integrate national energy markets have harmonized market rules and cross-border infrastructure investments. Significant progress has been made to harmonize rules, yet more cross-border interconnection capacity is needed to fully integrate the energy market. The integration of energy markets (i.e., electricity and gas) can be considered a regional club good, which suggests the benefits are nonexcludable to members of the network, and excludable to nonmembers.

An integrated energy market requires a common legislative framework (the "software") and crossborder infrastructure such as gas pipelines and electricity cables (the "hardware"). The EU has made significant progress on the software side, while the hardware side has experienced slower development. Attaining a fully integrated energy market was among the prerequisites to realizing the "Energy Union" to improve energy security, sustainability, and competitiveness, as presented by the European Commission in 2015.

On the software side, the EU has made significant progress. From 1996 to 2009, it adopted three legislative packages to harmonize regulation across energy markets in Europe and liberalize the internal energy market (Figure 5). The most recent, the Third Internal Energy Market Package, is a key step toward laying a legislative foundation for a joint energy market. The package promotes the unbundling of energy suppliers from transmission system operators in member states and seeks to strengthen the independence of national regulators. It also established the Agency for the Cooperation of Energy Regulators, which aims to enhance cooperation between national regulators and help resolve cross-border issues. In order to integrate transmission system operation across the EU, the package also created the European Networks of Transmission System Operators for Electricity and Gas. These organizations develop standards and draft network codes to harmonize cross-border flows of electricity and gas.

Progress has been slower on the hardware side. Electricity markets within the EU have developed either nationally or through regional pools. Similarly, gas flows have typically developed on a bilateral basis, through agreements between supplier consumer countries. These agreements were motivated by a supply-demand rationale rather than efforts to create an integrated gas market in Europe. Overall, therefore, the European electricity and gas markets remain largely fragmented.

In addition to ongoing support for cross-border infrastructure projects, the Connecting Europe Facility was established in 2013 to help bridge the infrastructure gap. The European Investment Bank has provided financial support for energy projects, including for cross-border infrastructure. The bank borrows on capital markets and lends at favorable terms to projects that support EU objectives. The bank has allocated more than $€ 161$ billion to these projects since 1959. The Connecting Europe Facility also directs EU investment in key cross-border infrastructure projects related to 


\section{Figure 5: The Road Toward the Third European Union Energy Package}

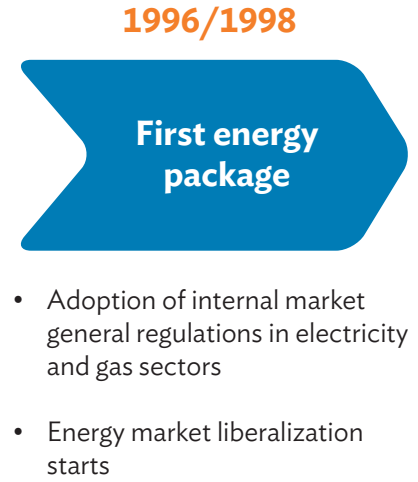

starts

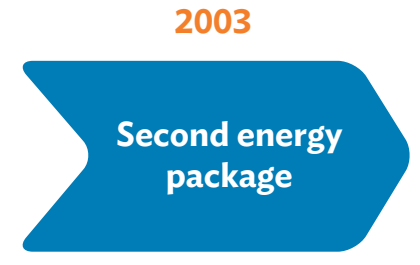

- Requirement to separate activities of energy sectorslegal and functional unbundling

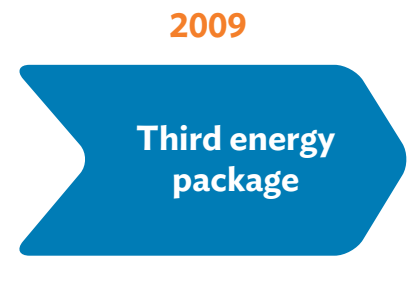

- Seeking to finalize the process of energy market liberalization and to ensure open and competitive market of energy resources

Source: Bernatonis (2013).

transport and information and communication technology. Its budget amounts to $€ 30.4$ billion for 2014-2020, with $€ 5.35$ billion allocated to energy sector projects..$^{10}$ Of that, $€ 4.7$ billion is available in grants that support EU Projects of Common Interest, infrastructure projects identified as key to linking the energy systems of member countries (Figure 6). They must satisfy the following conditions:

- have a significant impact on two or more EU countries,

- improve market integration and the integration of EU countries' networks,

- strengthen competition in energy markets by providing alternatives to consumers,

- improve security of supply, and

- contribute to the EU's energy and climate goals by improving the integration of energy from variable renewable sources.

Assessing the value of integrating energy markets requires analysis of benefits versus costs. On the one hand, enlarging the market may produce economies of scale and efficiency gains from better use of existing assets ("static" efficiency) and from regionally coordinated investment decisions in new assets ("dynamic" efficiency), shown in Table 9." On the other hand, integration can be costly where countries' preferences differ. The impact of energy market integration may therefore depend on whether efficiency gains outweigh transaction costs (Altomonte and Nava 2006).

Efficiency gains from integration are mainly from two sources (Zachmann 2013). First, the integration can increase competition, which may lead to better usage of inputs and reductions in firm costs. For instance, Shanefelter (2008) finds that moving from a regulated framework to market-based incentives enhances productive efficiency. Second, integration allows for the cross-border trade of electricity and efficiency gains from, among other things, the benefits of exchanging differences in resource endowments across countries (e.g., trading intermittent wind power for dispatchable hydropower) and the ability to maintain a more diversified generation mix.

${ }_{10} €_{24.1}$ billion was allocated to projects in the transport sector while $€ 1.04$ billion went to telecommunications sector projects.

"An example of static efficiency is the monetary gain from replacing electricity generation from an expensive coal plant in one country with cheaper wind power in another. Dynamic efficiency would arise from constructing only one coal plant to balance both systems instead of a separate plant in each country. 


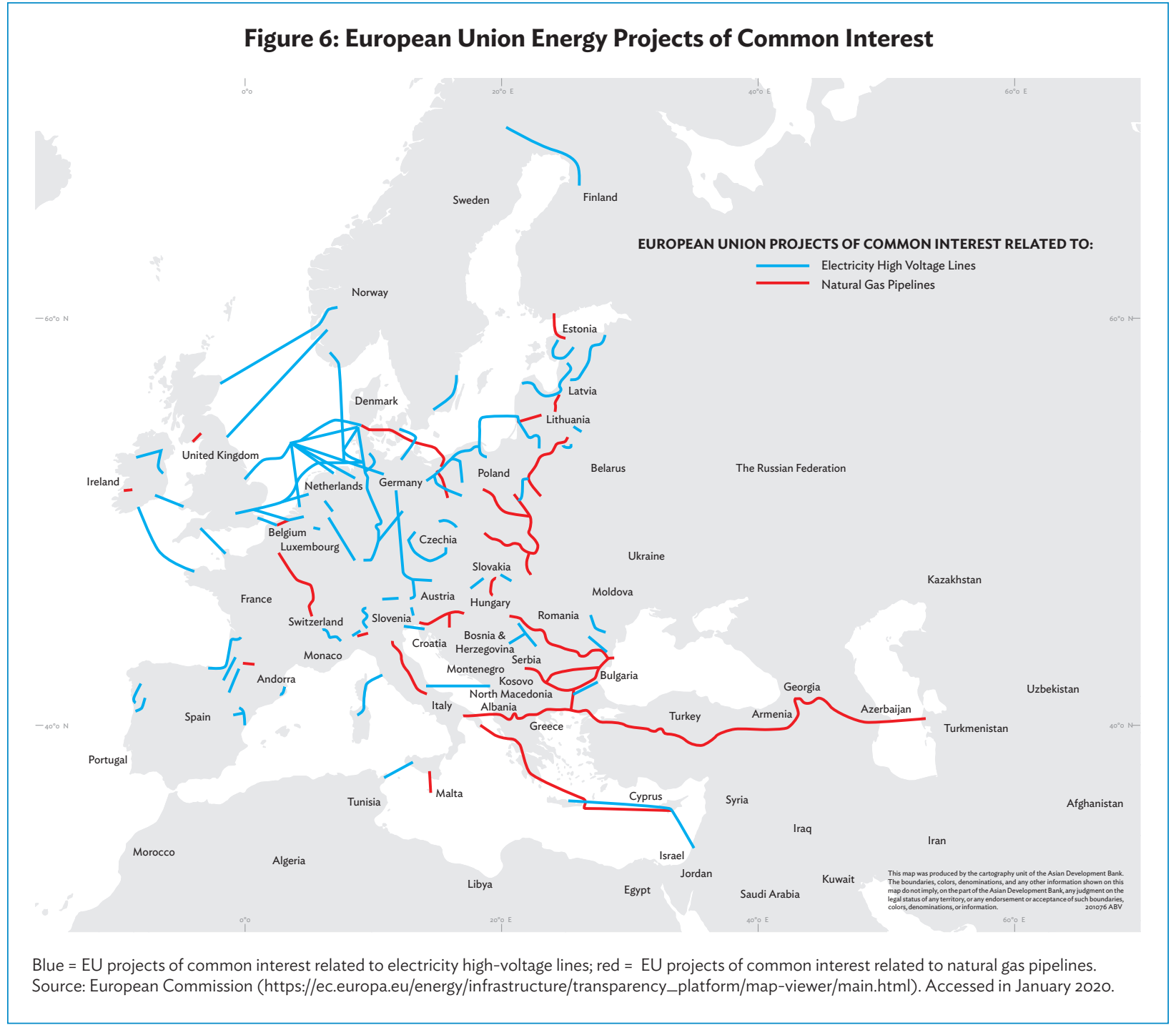

Table 9: Categorization of Potential Benefits from a Single Energy Market

\begin{tabular}{|c|c|c|}
\hline "Benefit" & Static Efficiency & Dynamic Efficiency \\
\hline $\begin{array}{l}\text { Competition-related } \\
\text { benefits }\end{array}$ & $\begin{array}{ll}\text { - } & \text { Reduced mark-ups } \\
\text { - } & \text { Improved operation }\end{array}$ & $\begin{array}{l}\text { - } \quad \text { Less investment withholding } \\
\text { - } \quad \text { Improved investment decisions }\end{array}$ \\
\hline $\begin{array}{l}\text { Integration-related } \\
\text { benefits }\end{array}$ & $\begin{array}{l}\text { - Cross-border optimization } \\
\text { of operation }\end{array}$ & $\begin{array}{l}\text { - Cross-border optimization of investment } \\
\text { decisions } \\
\text { - } \quad \text { Cross-border optimization of company structures } \\
\text { - } \quad \text { Better use of local resources }\end{array}$ \\
\hline
\end{tabular}

Source: Fredriksson, Marcus, Merler, Tagliapietra, and Wolff (2018). 
Energy market integration in Europe illustrates the weakest-link and best-shot technologies. Strengthening the energy infrastructure requires shoring up the capabilities of weakest-link economies and providing financial assistance. Harmonization of market rules in the EU has bestshot aggregation technology characteristics. Indeed, part of the joint market legislation is rooted in the regulatory experiences and best practices of member states. ${ }^{12}$

\section{Mitigating Overpricing in International Mobile Roaming}

International mobile roaming (IMR) offers subscriptions for users of mobile telecommunications services to use their mobile devices in other countries. For many years, governments around the world have expressed concerns that the price of IMR services seemed unreasonably higher than the price of domestic telecommunications services. An EU-wide approach to mobile roaming helped increase the consumption of IMR services, together with measures to reduce wholesale interoperator tariff charges and retail prices (Figure 7).

High prices are difficult to remedy because they result from rational profit-taking by different networks in two different countries - the incentives of the home network and the visited network tend not to be aligned, and they are regulated by different national authorities whose interests may also not be in step.

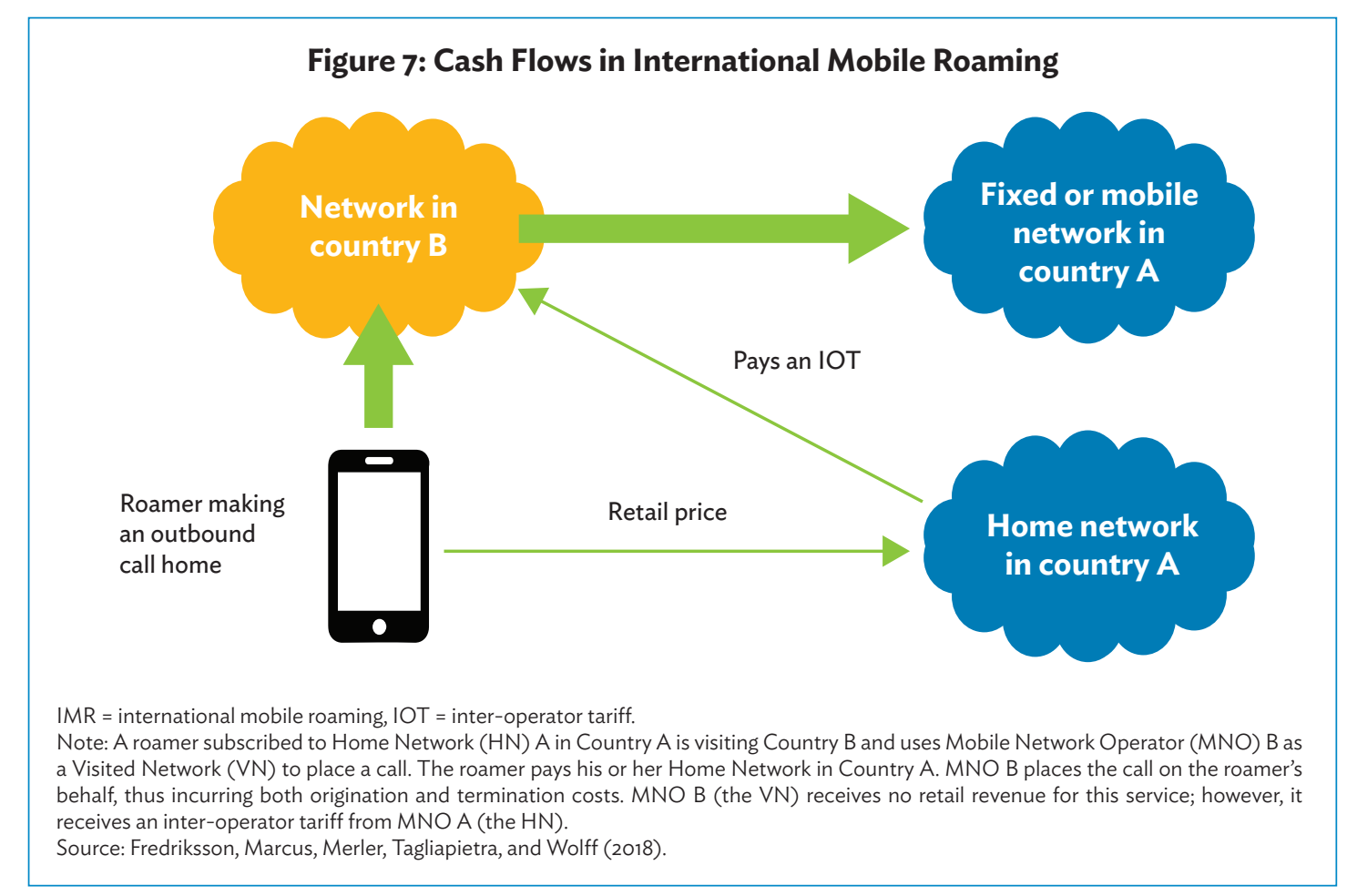

The EU initially tried to reduce high IMR prices through regulation from 2002 to 2007 based on competition law principles in each member state. This approach was unsuccessful because no single national regulator could cover issues in both the home and the visited networks. Beginning

12 An example includes the liberalization process of EU electricity markets being inspired by market reforms in the United Kingdom. (Karan and Kazdağli 2011; Albers 2001). 
2007, regulations introduced an EU-wide ${ }^{13}$ approach to mobile roaming. Tackling inflated prices associated with IMR can serve not only to increase consumer surplus, but also to strengthen regional integration and foster synergies among countries.

Before regulation in 2007, the inter-operator tariff payment for roaming voice calls placed in Europe averaged about $€ 1$ per minute, even though the cost to provide the service was probably just a few cents. To the home network, the tariff payment made to an unaffiliated visited network in a different country is a real cost - the underlying cost to the visited network of providing the service is irrelevant to the home network. The wholesale payment of $€ 1$ consequently resulted in average retail prices for roaming voice calls placed in Europe of about $€ 1.30$, a retail margin of about $25 \%-30 \%$ (Stumpf 2001).

Roaming regulations were amended in 2009, 2012, and 2015. In each case, both wholesale interoperator charges and retail prices were progressively reduced. The general approach had been to set a cap on wholesale charges, to require that a retail service be available with a capped price, and to ensure a spread of roughly $30 \%$ between the wholesale and retail caps. However, differences in the regulation of calls made, calls received, short messaging service (SMS), and data roaming were apparent, and largely because roaming services were delivered using different technical approaches. One of the measures the EU subsequently implemented was amending the Roam Like at Home, which took full effect in 2017. This prohibited network operators from charging for roaming any premium on the domestic prices of services. Wholesale rates have been capped at the lowest possible levels, possibly below cost for some network operators (Figure 8).

The measures effectively led to increased consumption of IMR services-far more so for roaming data than for voice calls made while roaming. The societal cost is substantial. An analysis conducted in preparation for the 2012 revisions to the EU Roaming Regulation suggests that demand for roaming voice services is not elastic, with a price elasticity of demand of -0.27 for calls made, -0.24 for calls received, and -0.24 for SMS. Overall, the cost to society over 2012-2014 would have been substantial, leading to a net loss of $€ 13.6$ billion in societal welfare (EC 2011).

13 It includes the $28 \mathrm{EU}$ member states and three European Economic Area countries: Iceland, Liechtenstein, and Norway. In the interest of brevity, we refer to an EU approach throughout. 
Figure 8: Average Wholesale Price per Minute for Wholesale Roaming Voice Calls (top) and Data per Megabyte (bottom)
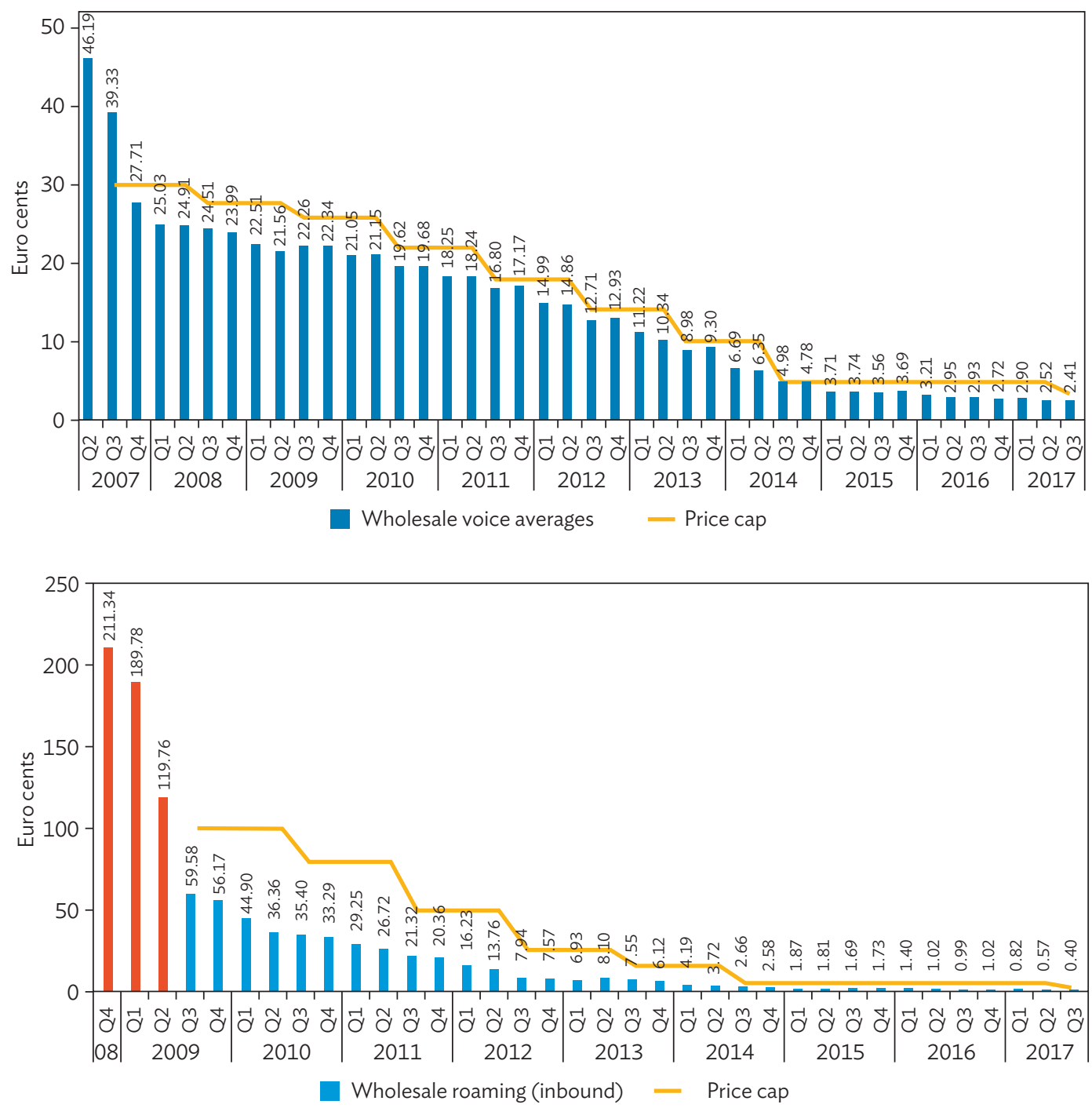


\section{Comparative Analysis of Europe and Asia}

Asia and Europe have followed different approaches to regionalism and RPGs. In Europe, the devastation from two world wars provided impetus to share sovereignty with regional neighbors and build more integrated economies and societies (Capannelli and Filippini 2009). It was thought that this approach would bring benefits beyond merely acting as a sum of individual policies. In Asia, regional integration has been driven more by markets than by governments, while cooperation among national authorities is more recent, stimulated by the Asian financial crisis of 1997 and focused mostly in East and Southeast Asia. It is focused more on economic issues and informal institutions than in Europe. Southeast Asian economies for instance adopt an "open regionalism" approach that stresses efficient competition in global markets and promotes the least discriminatory component with nonmember countries. There are no supranational bodies in Asia unlike in Europe with regional enforcement mechanisms. Despite these differences, the European experience provides lessons for effective RPG provision in Asia. The following areas are discussed: malaria elimination, energy market integration, and financial stability through regional financial arrangements. $A D B$ as a regional institution also supports these initiatives and others through its subregional programs to enhance regional cooperation in Asia and the Pacific. This encompasses the Greater Mekong Subregion (GMS) in Southeast Asia, the Central Asia Regional Economic Cooperation (CAREC) program, the South Asia Subregional Economic Cooperation (SASEC) Program, and other initiatives in the Pacific.

\section{Malaria Elimination}

While malaria eradication for isolated nations is considered a threshold public good, it requires a coordinated regional approach because of the threat of cross-border movement of disease vectors (e.g., malaria-infected mosquitoes and humans). For continental states, national and regional malaria elimination requires all to achieve the threshold of national elimination, as the threat of importation from incapable or uncooperative states will invalidate the collective effort. As seen earlier in this report, the eradication of malaria in the GMS therefore is both (i) a discrete RPG where supply is binary; malaria is eliminated or not eliminated, and (ii) a weakest-link RPG where contributions are non-additive and non-substitutive.

For a homogenous set of players, the effective supply of discrete and weakest-link RPGs is an assurance game, ${ }^{14}$ where the problem of provision is easily solvable by coordination (Holzinger 2000). For heterogeneous players, wealthier states need to increase the financial and technical capacity of poorer states to achieve the threshold of national elimination and secure the RPG supply (Rufin 2003). However, if all countries in the region have insufficient technical and financial capacity,

14 Weakest-link RPGs require an assurance game where there are two Nash equilibria (eliminate and not eliminate). 
the supply will depend on support from international organizations and richer nations from other regions, if the RPG has spillover benefits outside of the region (Sandler 2006).

The World Health Organization (WHO) in Europe played a key role in malaria control and elimination during the resurgence of the disease in the WHO European Region ${ }^{15}$ during the 1990s, focused mostly on Central Asian economies that are close to Europe. Nearly all national malaria control programs lacked dedicated staff and enough technical expertise to guide programs and were severely hampered by inadequate resources (WHO-Regional Office for Europe 2005). As a response, WHO introduced a regional strategy, Roll Back Malaria, in 1999 focused on Eastern Europe and Central Asia. This contributed to developing national malaria strategies, initiating crossborder and regional coordination, obtaining financing from donors such as the Global Fund to Fight AIDS, Tuberculosis and Malaria; and providing technical guidance and capacity building for malaria control activities (disease management, epidemic preparedness and response, integrated vector control, malaria surveillance, advocacy work and publications, research and development, and so on). WHO's successful efforts in controlling malaria shifted Europe's priorities to providing more ambitious public goods. In 2006, after a considerable drop in cases since 1999, WHO-Europe and the malaria-affected countries changed strategy from control to elimination, and in 2015, shifted to the prevention of malaria reintroduction after eliminating cases of indigenous malaria in the affected countries (WHO 2018).

WHO's success in Europe highlights the importance of international agencies in supplying RPGs where all states are financially or technically incapable of providing a national public good. Asia, including the GMS, follows this provision of weakest-link RPGs as highlighted by Sandler (2006) and the WHO's success in Europe. WHO and the Asia Pacific Malaria Elimination Network report that the GMS and the Asia and Pacific region have yet to gain the technical capacity to transition from malaria control to elimination (WHO 2015). WHO, along with the Asian Pacific Leaders Malaria Alliance and other institutions have been pursuing regional elimination in the GMS to achieve the larger goal of global elimination. In 2015, WHO published the Strategy for Malaria Elimination in the GMS (2015-2030). This emphasizes a progression from burden reduction to complete elimination with the priority to tackle multidrug resistance. Overall, WHO aims to strengthen and increase the scope of the health system, disease management, vector control, and malaria surveillance. The GMS is important for WHO's Global Technical Strategy for Malaria 20162030 to address multidrug resistance in the subregion and prevent it from spreading to vulnerable regions like Africa. Considering the success of Europe, the inclusion of regional institutions in Asia aims to create greater coordination toward malaria elimination in the GMS. The Asian Pacific Leaders Malaria Alliance provides technical guidance and coordination and the Regional Malaria and Other Communicable Disease Threats Trust Fund provides financing and encouraging donor participation. For its part, $A D B$ as a regional institution has been supporting the trust fund through financing and capacity building activities in the GMS. Since 2006, ADB has been supporting several communicable disease control projects in this subregion, including a recent technical assistance that focused on malaria by targeting vulnerable groups especially mobile and migrant populations, strengthening diagnostic and treatment capacity in remote districts, improving disease surveillance and rapid response, and involving the private sector in the delivery of health services to vulnerable groups (ADB, 2015).

15 WHO-Europe Malaria affected countries included Armenia, Azerbaijan, Georgia, the Kyrgyz Republic, Tajikistan, Turkmenistan, Turkey, and Uzbekistan. 


\section{Energy Market Integration}

The benefits of EU energy market integration-security of supply, lower energy prices, and a stable electrical grid-can be realized through a common legislative framework (software) and crossborder infrastructure (hardware). European energy market integration illustrates the weakest-link, weighted sum, and best-shot aggregation technologies. Providing financial assistance to weakestlink economies strengthens energy market interconnectedness among member states. The construction of cross-border infrastructure follows a weighted-sum aggregation technology since economies usually contribute varying amounts to such projects (Andrews-Speed 2011). Market rules harmonization is best done by countries that successfully regulated their own market, i.e., adopting best practices leads to effective joint market legislation.

An important lesson from the European experience is that developing software for an integrated energy market requires both political willingness and technical cooperation. Specifically, this requires progress in the adoption of legislative packages and harmonized laws. On the other hand, developing the hardware still must make progress as the Energy Union is still expanding the interconnection of gas and electricity market across borders. Andrews-Speed (2011) notes that the energy market integration requires not only trade and investment liberalization, but also energy infrastructure linkage, domestic pricing systems for energy reform, and national energy market liberalization.

The development of an integrated energy market requires relatively sophisticated systems of energy governance. Some will need to be legally binding and may require states to yield some authority to a supranational institution. Moreover, governments may be required to cede ownership over state-run energy enterprises to promote investment inflows to primary energy resources. Decades may be needed to make significant progress on some of these governance issues, as the EU experience shows.

The EU has many advantages over the East and Southeast Asian region in geographical size and contiguity, political and economic outlook, and the success in integrating markets for other goods and services. Experience also shows that full monetary integration in Europe can only proceed as rapidly as the slowest nation, or at least as the slowest nation with a key role to play in the market.

Several factors in East and Southeast Asia (including Australia, India, and New Zealand) tend to support steps to energy market integration (Andrews-Speed 2011). These include geographic contiguity, though over a vast distance; certain commonalities of outlook and a general willingness to cooperate on economic issues (Dent 2008); complementarity across the region in energy supply and demand and the energy mix; some countries with advanced economies and technological expertise to act as best-shot or better-shot suppliers of public goods (e.g., Australia, Japan, the Republic of Korea); and countries which, in principle, can show political leadership in the integration process (e.g., New Zealand, the PRC, Singapore).

Constraining factors include: the large geographic size of East and Southeast Asia, along with the significant physical barriers across the region such as oceans and mountain ranges; very different histories, cultures, economies, and politics; long-standing rivalries between nations that could provide leadership, and unresolved security challenges and strong emphasis on national sovereignty (Gurtov 2002; Lincoln 2004; Rozman 2004); several very poor countries in key locations that could prove to be weaker link actors in the management of regional infrastructure (e.g., Cambodia, the Lao People's Democratic Republic, Myanmar); and high variability between the national energy sectors in regard to degrees of development, ownership, market structure, and policy priorities. These concerns will 
affect the provision of specific services such as dissemination of research results and issues relating to perceptions of national security, national sovereignty, and state control of the energy industry. Further, these will restrict development of effective governance systems in the region and the speed at which market barriers fall (Andrews-Speed 2011).

The European experience suggests that integration should be pursued first at the subregional level, where delivery of specific services will support the development of an integrated energy market (Andrews-Speed 2011). Delivery of specific energy services is best considered according to their degree of publicness and aggregation technology. The construction of transboundary infrastructure is in many respects a club good (though the operation of it has wider public goods benefits) and can therefore be delivered with a discrete number of willing and competent states. This subregional approach is being undertaken by ADB to promote cross-border energy trade and supply security in the region. In both Central and South Asia, countries are rich in renewable resources although these are unevenly distributed. In Central Asia, ADB through CAREC is helping enhance harmonization and finance infrastructure for regional electricity trade as well as developing the East-Central AsiaSouth Asia Regional Energy Market. In support of CAREC's latest energy strategy for 2030, a new institutional setup is being formed to promote greater interconnection of energy networks: the Central Asia Transmission Cooperation Association will be established to enable network operators to discuss and produce longer-term regional network development plans (CAREC 2019). In South Asia, SASEC is helping to improve connectivity of cross-border electricity transmission, increase power trade, and enhance capacity development.

In East and Southeast Asia, several initiatives are being undertaken. These include technological research and development and the establishment and harmonization of technical standards. These will provide long-term support to progressive energy market integration. Moreover, openness and governance at national level are key prerequisites for integration to proceed and deliver significant regional benefits. Examples of initiatives that can be encouraged and pursued are the TransASEAN Gas Pipeline, the ASEAN Power Grid, and proposals for subregional energy networks in Northeast Asia.

\section{Regional Financial Stability}

The pursuit of financial stability as an RPG can be said to follow weakest-link, as it entails a large degree of cross-border spillover effects when one country has poor financial practices. The euro area crisis showed that seemingly small problems in local banking sectors could spill over to other countries and turn into existential systemic threats. Europe addressed its weakest-link problem by implementing harmonized financial regulation as a crisis prevention measure to eliminate the risk in its weakest states.

The European experience shows coordination is easier to achieve than voluntary cooperation. Despite the presence of policies which aimed to harmonize banking regulation already in place by 1977, the lack of effective national enforcement and accountability of these rules exposed the region to negative spillovers presented by states with weaker banking regulation enforcement. Europe addressed the diversity in regulatory quality by shifting bank supervisory authority from the national to the regional level, delegating it to a regional supervisory institution, the Single Supervisory Mechanism. Among reforms and policies implemented in Europe to achieve financial stability, the mechanism has already made significant contributions to mitigate future crises (Darvas, Schoenmaker, and Véron 2018). 
Although the success of regional supervisory institutions in Europe holds important lessons for Asian regional financial stability, Asian economies are much more diverse in their economic development, institutional capacity, and financial market depth and openness than European economies. This suggests that the European experience is an important reference point, even as it is not a template or a benchmark, and that appropriate financial regulatory cooperation and types of regional institutions will differ substantially from those developed in Europe (Morgan 2018).

The main difference lies in Asia's lack of political structure and legislative power to enforce regional cooperation in the same vein as the European Union. While intergovernmental cooperation has already developed several forums, initiatives and mechanisms, ${ }^{16}$ the only "Asian" institution with a proper representative function of its member states, run by professional staff working for the region's interest (not for their own countries' interests) is the ASEAN Secretariat. However, the secretariat's political weight is limited because it needs Japan and the PRC, at least, to move toward a truly regional agenda. As such, regulatory quality in Asia remains diverse. ${ }^{17}$ The priority in Asia should be to promote financial development in its weakest states. That is because regulatory harmonization without effective enforcement can still lead to failure-as shown by the European experience. Another issue that needs to be solved is the implementation of harmonized laws and regulations in the Asian context, where there is little willingness to concede national sovereignty in these areas (Morgan 2018). Darvas, Schoenmaker, and Véron (2018) suggest that a realistic approach in Asia is to create more of a web of bilateral or multilateral "equivalency" frameworks than a fully-fledged sector-wide system of supranational rulemaking. Bilateral agreements are easier to sustain as reciprocity- "tit-for-tat" negotiation-works in bilateral arrangements but not well for multilateral deals (Barrett 2018).

The formation of financial stability networks also highlights the importance of regional institutions in coordinating RPG provision. Experiences in ASEAN and the European Union influenced both the creation of the Chiang Mai Initiative and its ensuing financial mechanism in Asia, and the European Financial Stability Fund, the European Financial Security Mechanism and the European Stability Mechanism. However, unlike European financial stability networks, which succeeded during the European sovereign debt crisis, funds from the Chiang Mai Initiative have not been used, even during the 2007-2009 global financial crisis. So while the Republic of Korea and Indonesia experienced international liquidity shortages, they elected to borrow from other channels because of the Chiang Mai Initiative's perceived weaknesses, including: (i) The stigma of a relationship with the International Monetary Fund (IMF), brought by IMF-linked portion (10\%); (ii) a cumbersome and untested release of funds; and (iii) perceptions that the borrowing quota ( $\$ 84$ billion committed bilateral swap lines) is inadequate (Kawai 2015).

The establishment of the expanded Chiang Mai Initiative Mechanism and its amendment in 2012 aimed to tackle some of these concerns by increasing the committed amount to $\$ 240$ billion and increasing the IMF de-linked portion to 30\%. However, the mechanism remains unlikely to be successful in crisis prevention and management because of the present ad hoc modality of cooperation between the ASEAN+3 regional financial stability network and the IMF,

${ }_{16}$ Included are the Economic Review and Policy Dialogue, Executive's Meeting of East-Asia Pacific Central Banks, which promote financial cooperation and better policies.

17 According to the World Bank World Governance Indicators, Asian countries' rankings range from the 1.9-100 percentile, in contrast to Europe where the range is 71.1-99.5 percentile. The regulatory rankings of Cambodia (39.2 percentile), the Lao People's Democratic Republic (22.0), Myanmar (1.9), and Viet Nam (27.3) lag the region. 
and the relatively small size of available funding and its cumbersome disbursement procedures. ${ }^{18}$ The $\$ 240$ billion commitments are inadequate to prevent and manage the newer types of capital account crisis associated with large inflows and a sudden withdrawal of short-term financial capital. The economic and social costs and the contagion effects of a capital account crisis tend to be high (Rana 2018). The Chiang Mai Initiative Mechanism is less than 1\% of ASEAN+3 GDP, while the European Stability Mechanism is about $4.2 \%$ of GDP in the EU. To add context, the maximum swap amount for the Republic of Korea ( $\$ 38.4$ billion) and Indonesia ( $\$ 23$ billion) is smaller than the IMF packages both countries received during the Asian financial crisis $-\$ 58.2$ billion for the Republic of Korea and $\$ 42.3$ billion for Indonesia. During the sovereign debt crisis in Europe, two packages of $\$ 142$ billion and $\$ 130$ billion were put together for Greece, and a $\$ 100$ billion package was assembled for Portugal. Therefore, to ensure the success of the Chiang Mai Initiative Mechanism, the committed amount and IMF de-linked portion should increase to not less than $4 \%$ to reflect the scale of the more recent crisis response in Europe.

The primacy of EU law contributed to the European Stability Mechanism relative to that of Asia. EU law requires each euro area state to contribute paid-in capital, which makes funds readily available in times of crisis. In contrast, the Chiang Mai Initiative Mechanism consists of unenforceable central bank commitments and lacks measures to ensure quick disbursement of funds needed in a crisis. ${ }^{19}$ Therefore, similar measures such as paid-in capital contributions should be enforced to make disbursements effective. However, like the problem of regulatory harmonization in Asia, the lack of binding legislation is an issue for enforcing capital contributions. Hur (2019) suggests coordinating with IMF to classify paid-in capital contributions to the Chiang Mai Initiative as international reserves to incentivize paid-in capital contributions.

18 ASEAN+3 includes the 10 members of the Association of Southeast Asian Nations (Brunei Darussalam, Cambodia, Indonesia, the Lao People's Democratic Republic, Malaysia, Myanmar, the Philippines, Singapore, Thailand, and Viet Nam) plus the PRC, Japan, and the Republic of Korea.

19 Europe's regional financial safety net, the European Stability Mechanism (ESM), consists of $€ 700$ billion in capital contributions from European Area Member States in the form of $€ 80$ billion subscribed capital and $€ 620$ billion in callable shares. Asia's regional financial stability network, the Chiang Mai Initiative Multilateralization, consists of $\$ 240$ billion committed funds from the 13 members of the ASEAN+3 region. 


\section{Conclusions}

The provision of RPGs is closely related to regional cooperation and integration. European experiences in malaria elimination, energy market integration, and regional financial stability have highlighted the important role of regional institutions in promoting regional cooperation and integration and the provision of RPGs. European regional institutions such as WHO-EUROPE, EU, and European Central Bank have provided mechanisms through which cooperation, coordination, and decision-making are efficient and effective.

Although successes of Europe's regional institutions stand as valuable lessons for Asia, they cannot be translated one-to-one in Asia because of contextual differences such as great diversity in economic and financial development, and institutional capacity. Asia can focus first on identifying types of RPGs in needs and related stakeholders for more efficient and effective provision. Policy recommendations should differ depending on the assessment: for example, weakest-link countries can be supported though funding and capacity building, while best-shot countries can help design and disseminate best practices and policy standards to help weaker countries. More importantly, Asia lacks a regional institution that commands the legislative power of the EU. The primacy of EU law assures that member states are bound to its decisions, and resolves the issues of prisoner's dilemma and free-riding. With no legal authority to enforce cooperation and the largely voluntary nature of such cooperation in Asia, strong pressure is needed for more effective results to be produced (Morgan 2018).

Despite the absence of statutory mechanisms to tax and supply RPGs, there is still plenty of scope in Asia for RPG provision toward mutually beneficial arrangements. The theory of repeated games suggests that self-enforcing voluntary cooperation is feasible through continuous interactions. Recognizing repeated interactions with the same members in the future will help reduce opportunistic behavior, leading to socially optimum results (so-called "the shadow of the future"). Therefore, regional forums can be considered as venues where member countries can build trust and cooperate without the need for third-party enforcement or supranational institutions. In Asia, the subregional programs supported by ADB such as the GMS, CAREC, and SASEC can be useful platforms to foster repeated long-term relationships among the member economies.

The case studies for Asia show that RPG provision can be initiated and supported by agreements and declarations rather than the formal institutions established in Europe. In the tsunami warning system, detection and reporting are RPGs handled by more advanced economies, while communications and responses are national. Regional fisheries management in the Pacific is governed by agreements rather than a formal supranational organization that oversees the surveillance done by individual governments. Control and elimination of malaria is also based on a declaration in the 2014 East Asia Summit, and supported by a trust fund in a regional institution (ADB) to support multicountry and multisector responses to malaria and other communicable diseases. In Asia and the Pacific, many 
regional and subregional forums are emerging which can serve as platforms to build mutual trust and generate self-enforcing voluntary cooperation on issues of common interests through regular meetings and interactions. These can lead to collective actions to develop and deploy vaccines and treatments for infectious diseases including COVID-19. Meanwhile, management of the Mekong River basin leaves room for improvement as the lower basin economies cooperate through the Mekong River Commission while the upstream economies (Myanmar and the PRC) are mere dialogue partners.

The case studies also illustrate the superior benefits from forging a regional approach rather than countries initiating policies on their own. This underscores the role of regional institutions to bring countries toward regional cooperation. Multilateral development banks can provide needed "strong pressure" and can help increase RPG provision through narrowing knowledge and financing gaps, providing a permanent platform for continuous dialogue, and by being honest brokers to enhance mutual trust and facilitate regional cooperation for RPG provision. Their in-depth knowledge and experiences across multiple countries and sectors allow a more holistic and integrated approach to dealing with regional and subregional development issues and so promote regional cooperation for RPG provision that can complement national efforts. Moreover, coordination among global, regional, and subregional institutions can also enhance RPG provision through complementarity and alignment of goals and strategies. However, multilateral development banks still have limited roles in enforcing cooperation because they lack political and legislative powers.

It then becomes important that noncooperative parties realize the trade-off between RPG provision and integration. A strategic approach to multilateral coordination-an indirect way of structuring an agreement to induce collaboration-helps create a detailed picture of balancing the results of factors such as trade provisions included in international agreements (such as the Montreal protocol). ${ }^{20}$ Lastly, multilateral development banks and other regional institutions should work with other subregional and global institutions to complement each other's different roles.

${ }_{20}$ Barrett (2018b) argues that there are two ways in which enforcement can be incorporated into an agreement, direct and strategic, "The direct approach involves asking countries to supply the public good, and then figuring out how these obligations to supply can be enforced. The strategic approach involves identifying opportunities for enforcement and then structuring the agreement to exploit these opportunities." For multilateral agreements, the strategic approach is more applicable. For example, the Montreal Protocol aims to protect the ozone layer not only by requiring that parties contribute to the public good by reducing their consumption and production of chlorofluorocarbons. It also requires that the parties to the agreement not trade in chlorofluorocarbons or products containing them with parties not part of the agreement. 


\section{Background Papers}

Barrett, S. 2018a. "Regional Public Goods: Conceptual Foundations." Background paper for the Asian Economic Integration Report 2018 theme chapter "Toward Optimal Provision of Regional Public Goods in Asia and the Pacific." Manuscript. . 2018b. "Regional Public Goods: Case Studies in Asia-Pacific." Background paper for the Asian Economic Integration Report 2018 theme chapter "Toward Optimal Provision of Regional Public Goods in Asia and the Pacific." Manuscript.

Fredriksson, G., J. Marcus, S. Merler, S. Tagliapietra, and G. Wolff. 2018. "An Empirical Analysis and Case Studies of RPG Provision in Europe." Background paper for the Asian Economic Integration Report 2018 theme chapter "Toward Optimal Provision of Regional Public Goods in Asia and the Pacific." Manuscript. . 2018. "Policy Recommendations with Regard to RPG Provision in Asia." Background paper for the Asian Economic Integration Report 2018 theme chapter "Toward Optimal Provision of Regional Public Goods in Asia and the Pacific." Manuscript.

Sandler, T. 2018a. Regional Public Goods and Their Technologies of Aggregation. Background paper for the Asian Economic Integration Report 2018 Theme Chapter on "Toward Optimal Provision of Regional Public Goods in Asia and the Pacific." Manuscript. . 2018b. Functional Areas, Aggregator Technologies, and Policy Recommendations. Background note for the Asian Economic Integration Report 2018 Theme Chapter on "Toward Optimal Provision of Regional Public Goods in Asia and the Pacific." Manuscript.

\section{References}

Albers, M. 2001. "Energy Liberalisation and EC Competition Law." Fordham 28th Annual Conference of Antitrust Law and Policy. http://ec.europa.eu/competition/speeches/text/ sp2001_028_en.pdf

Altomonte, C., and M. Nava. 2006. Economics and Policies of an Enlarged Europe. Cheltenham: Edward Elgar Publishing.

Alverson, K. 2005. "Watching Over the World's Oceans." Nature 434 (7029): 19-20.

Andrews-Speed, P. 2011. "Energy Market Integration in East Asia: A Regional Public Goods Approach.” ERIA Discussion Paper Series 2011-06, Economic Research Institute for ASEAN and East Asia, Jakarta.

Asian Development Bank (ADB). 2015. Malaria Elimination: An Entry Point for Strengthening Health Systems and Regional Health Security, and a Public Health Best-Buy. Manila. 2015. Malaria and Communicable Diseases Control in the Greater Mekong Subregion. Technical Assistance Report. Project Number 48446-001. Manila. https://www.adb.org/ sites/default/files/project-document/174939/48446-001-tar.pdf 2016. ADB $\$ 125$ Million Loan and Grant to Strengthen Health Security in GMS. News release, 23 November. https://www.adb.org/news/adb-125-million-loan-and-grantstrengthen-health-security-gms 2018. Asian Economic Integration Report 2018: Toward Optimal Provision of Regional Public Goods in Asia and the Pacific. Manila. 
2020. Regional: Greater Mekong Subregion Health Security Project. Project documents. https://www.adb.org/projects/48118-002/main\#project-documents

Barrett, S. 2003. Environment and Statecraft: The Strategy of Environmental Treaty-Making. Oxford: Oxford University Press.

Body of European Regulators for Electronic Communications (BEREC). 2018, International Roaming: BEREC Benchmark Data Report, April 2017 - September 2017, BoR (18) 31.

Bernatonis, V. 2013. Role of Gas in Energy Security and Future Energy Market Direction. Presentation slides

Capannelli, G., and C. Filippini. 2009. "East Asian and European Economic Integration: A Comparative Analysis." Working Papers on Regional Economic Integration, Asian Development Bank, Manila.

Central Asia Regional and Economic Cooperation (CAREC). 2019. CAREC Energy Strategy 2030. Manila: Asian Development Bank. https://www.adb.org/sites/default/files/institutionaldocument/536941/carec-energy-strategy-2030.pdf

Chung, S. Y. 2017. “Building Regional Environmental Governance: Northeast Asia's Unique Path to Sustainable Development." In 21st-Century Cooperation, Regional Public Goods, and Sustainable Development, edited by A. Estevadeordal and L. W. Goodman. London and New York: Routledge.

Claeys, G. 2017. “The Missing Pieces of the Euro Architecture.” Policy Contribution 2017/28. Brussels: Bruegel.

Collier, P., V. Elliott, H. Hegre, A. Hoeffler, M. Reynal-Querol, and N. Sambanis. 2003. Breaking the Conflict Trap: Civil War and Development Policy. Washington, DC: World Bank and Oxford University Press.

Cornes, R. 1993. "Dyke Maintenance and Other Stories: Some Neglected Types of Public Goods." Quarterly Journal of Economics 108 (1): 259-271.

Cornes, R., and T. Sandler. 1996. The Theory of Externalities, Public Goods, and Club Goods. Cambridge: Cambridge University Press.

Darvas, Z., D. Schoenmaker, and N. Véron. 2016. "Reform of the European Union Financial Supervisory and Regulatory Architecture and its Implications for Asia." ADBI Working Paper Series. 615, ADB Institute, Tokyo.

. 2018. "Reforms to the European Union Financial Supervisory and Regulatory Architecture and their Implications for Asia." In Global Shocks and the New Global and Regional Financial Architecture, edited by N. Yoshino, P. B. Rana, and P. J. Morgan. (272-312). Asian Development Bank Institute and S. Rajaratnam School of International Studies. Tokyo/ Singapore.

Dent, C.M. 2008. East Asian Regionalism. London: Routledge.

Dinar, S. 2006. "Assessing Side-Payment and Cost-Sharing Patterns in International Water Agreements: The Geographic and Economic Connection." Political Geography 25: 412-437.

Eichengreen, B. J. 2007. The European Economy Since 1945: Coordinated Capitalism and Beyond. Princeton: Princeton University Press.

Estevadeordal, A. and L. W. Goodman, eds. 2017. 21st-Century Cooperation, Regional Public Goods, and Sustainable Development. London and New York: Routledge.

European Commission. 2011. Impact Assessment of Policy Options in Relation to the Commission's Review of the Functioning of Regulation (EC) No 544/2009 of the European Parliament and of the Council of 18 June 2009 on Roaming on Public Mobile Telephone Networks within the Community. https://eur-lex.europa.eu/legal-content/EN/TXT/PDF/?uri=CELEX:52011SC08 70\&from $=$ EN

European Commission. 2018. Connecting Europe Facility. https:/ec.europa.eu/transport/themes/ infrastructure/ten-t-guidelines/ project-funding/cef_en (accessed September 2018). 
European Commission. (n.d.-a). Market legislation. Retrieved February 12, 2018, from European Commission: https://ec.europa.eu/energy/en/topics/markets-and-consumers/marketlegislation

European Commission. (n.d.-b). Projects of common interest - Interactive map. Retrieved May 1, 2018, from European Commission: http://ec.europa.eu/energy/infrastructure/transparency_ platform/map-viewer/main.html

European Commission's Expert Group. 2017. Towards Sustainable and Integrated European Energy Networks: Final Report by Commission Expert Group on 2030 Electricity Interconnection Targets. Brussels.

Gurtov, M. 2002. Pacific Asia? Prospects for Security and Cooperation in East Asia. Lanham, Maryland: Rowman and Littlefield.

Hardin, R. 1997. "Economic Theories of the State." In Perspectives on Public Choice: A Handbook, edited by D. C. Mueller. New York: Cambridge University Press.

Holzinger, K. 2001. "Aggregation Technology of Common Goods and its Strategic Consequences: Global Warming, Biodiversity, and Siting Conflicts." European Journal of Political Research 40: 117-138.

Hur, K.W. 2019. The Future of the Asian Regional Financial Arrangement. Lecture prepared for the Asia Though Leadership Series. Manila. 25 March

Intergovernmental Oceanographic Commission of United Nations Educational, Scientific and Cultural Organization (IOC/UNESCO). 2015. Indian Ocean Tsunami Warning and Mitigation System (IOTWMS) 2005-2015. Paris.

Karan, M. B., and H. Kazdağli. 2011. "The Development of Energy Markets in Europe." In Financial Aspects in Energy, edited by A. Dorsman, W. Westerman, M. B. Karan, and Ö Arslan. Berlin: Springer.

Kawai, M. 2015. "From the Chiang Mai Initiative to an Asian Monetary Fund." ADBI Working Paper Series No. 527, Asian Development Bank Institute, Tokyo.

Lincoln, E. J. 2004. East Asia. Economic Realism. Washington, DC: Brookings Press.

McNamara, K. 1998. The Currency of Ideas. Ithaca: Cornell University Press.

Moonen, B., S. Barrett, J. Tulloch, and D. T. Jamison. 2009. In Shrinking the Map: A Prospectus on Malaria Elimination, edited by R. Feachem, A. Phillips, and G. Targett. (1-18). San Francisco: The Global Health Group, Global Health Sciences, University of San Francisco.

Morgan, P. 2018. "Regional Financial Regulation in Asia." In Global Shocks and the New Global and Regional Financial Architecture, edited by N. Yoshino, P. B. Rana, and P. J. Morgan. (313346). Asian Development Bank Institute and S. Rajaratnam School of International Studies. Tokyo/Singapore.

Musgrave, R.A. 1969. "Provision for Social Goods." In Public Economics: An Analysis of Public Production and Consumption and their Relations to the Private Sectors, edited by J. Margolis, and H. Guitton. London: Macmillan.

Olson, M. 1965. The Logic of Collective Action: Public Goods and the Theory of Groups. Cambridge, MA: Harvard University Press. .1969. “The Principle of 'Fiscal Equivalence': The Division of Responsibilities among Different Levels of Government.” American Economic Review 59 (2): 478-487.

Pham Do, K. H. and A. Dinar. 2014. "The Role of Issue Linkage in Managing Cooperating Basins: The Case of the Mekong." Natural Resource Modeling 27 (4): 492-518.

Rana, P. 2018. "The Evolving Multilayered Global Financial Safety Net: The Case of the Association of Southeast Asian Nations +3 (ASEAN+3) Regional Financial Safety Net and the International Monetary Fund." In Global Shocks and the New Global and Regional Financial Architecture, edited by N. Yoshino, P. B. Rana, and P. J. Morgan. (248-271). Asian Development Bank Institute. 
Roberts, L. 2016. “Malaria Wars.” Science 352 (6284): 398-405.

Rozman, G. 2004. Northeast Asia's Stunted Regionalism. Bilateral Distrust in the Shadow of Globalization. Cambridge: Cambridge University Press.

Rufin, C. 2003. "Regional Public Goods and Infrastructure." In Regional Public Goods: From Theory to Practice, edited by A. Estevadeordal, B. Frantz, and T.R. Nguyen. (181-202). Inter-American Development Bank and Asian Development Bank. Washington DC.

Samuelson, P. A. 1954. "The Pure Theory of Public Expenditure." Review of Economics and Statistics 36 (4): 387-389.

Samuelson, P. A. 1955. "Diagrammatic Exposition of a Theory of Public Expenditure." Review of Economics and Statistics 37: 350-356.

Sandler, T. 1992. "After the Cold War, Secure the Global Commons." Taylor and Francis Journals 35 (4): 16-23.

Sandler, T. 2004. Global Collective Action. Cambridge: Cambridge University Press.

Sandler, T. 2006. "Regional Public Goods and International Organizations." The Review of International Organizations 1 (1): 5-25.

Sandler, T. 2013. "Public Goods and Regional Cooperation for Development: A New Look." Integration and Trade Journal 17 (1): 13-24.

Sandler, T., and D. Arce. 2002. "A Conceptual Framework for Understanding Global and Transnational Public Goods for Health." Fiscal Studies 23 (2): 195-222.

Shanefelter, J.K. 2008. Restructuring, Ownership and Efficiency: The Case of Labor in Electricity Generation. UC Berkeley: Center for the Study of Energy Markets.

Stumpf, U. 2001. "Prospects for Improving Competition in Mobile Roaming." Background paper for the Telecommunications Policy Research Conference. 27-29 October, Alexandria, VA.

Western and Central Pacific Fisheries Commission (WCPFC). 2016. Proposal for CMM for the Special Management of Certain High Seas Areas. https://www.wcpfc.int/node/28456

Wolf, A. T., J. A. Natharius, J. J. Danielson, B. S. Ward, and J. K. Pender. 1999. "International River Basins of the World.” International Journal of Water Resources Development 15 (4): 387-427.

World Bank. 2017. The Sunken Billions Revisited: Progress and Challenges in Global Marine Fisheries. Washington, DC.

World Health Organization (WHO)-Regional Office for Europe. 2005. Scaling Up the Response to Malaria in the WHO European Region: Progress Towards Curbing an Epidemic, 2000-2004. Copenhagen. 2015. Strategy for Malaria Elimination in the Greater Mekong Subregion (2015-2030). Geneva. 2018. World Malaria Report 2017. Geneva.

Yeeting, A. D., S. R. Bush, V. Ram-Bidesi, and M. Bailey. 2016. "Implications of New Economic Policy Instruments for Tuna Management in the Western and Central Pacific." Marine Policy 63: 45-52.

Zachmann, G. 2013. Electricity Without Borders: A Plan to Make the Internal Market Work. Bruegel Blueprint Series. Brussels. 



\section{Regional Public Goods in Asia and Europe}

As economies become more integrated, development challenges are becoming more transnational. The provision of regional public goods (RPGs) can address such challenges. RPGs can play an important role in sustainable economic development at the national and regional levels by addressing common issues across borders. This report reviews the concept of RPGs along with the challenges and benefits of their provision in Asia and Europe. It presents case studies and a comparative analysis of the arrangements taken toward RPG provision in both regions, offering lessons for Asia.

\section{About the Asian Development Bank}

ADB is committed to achieving a prosperous, inclusive, resilient, and sustainable Asia and the Pacific, while sustaining its efforts to eradicate extreme poverty. Established in 1966, it is owned by 68 members -49 from the region. Its main instruments for helping its developing member countries are policy dialogue, loans, equity investments, guarantees, grants, and technical assistance. 